A major purpose or tne I ecrirlcal Information Center is to provide the broadest dissemination possible of information contained in DOE's Research and Development Feports to business, industry, the academic community, and federal, state and local governments.

Although a small portion of this report is not reproducible, it is being made available to expedite the availability of information on the research discussed herein. 
authons: G. F. Jonus, K. A. Meyer, and J. C. Hedstrom Los Alamos National Laboratory

\author{
D. P. Grimmer \\ New Mexico Solar Energy Institute \\ Las Cruces, New Mexico 88003
}

suamitted to Jet Propulsior. Laboratory

R. L. French

4800 Oak Grove Orive

Pasadena, Californta

91109

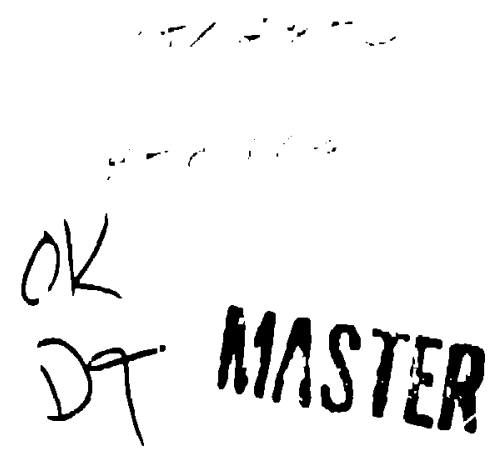

\title{
DISC 'LAIMRR
}

This report way prepared as un aciount of work sponsored hy an agency of the United Stales (ioverninent. Neither the Uniled Silutes (jovernment nor any ugency thereof, nor uny of their employees, mukes uny warrunty, express of implied, or ansumes nny legul liability or responnibility for the accuracy, completeness, or unefulnow of any informution, apparatus, product, or prixess disclosed, or represents that its use would not infring: privately owned richts. Refer. ence herein to uny specific commerciul preslucl, pricenn, or kervice by trude nume, Irudemurk, munufucturer, of wherwise does not necensarily constitute or imply lis endursement, tecom. mendution, or favoring by the United Stutes diovernment or any agency thereof. The viows und opinions of authors expressed herein do not necensurily slute or reflect those of the United Situles fiovernmeill of uny ugency thereor. 
ABSTRACT . . . . . . . . . . . . . . . . . . 1

1. prograM oescription ...................... 2

11. THE THEORY OF SOLAR POHOS .................... 2

A. Intarfactal Boundary Ldyer Model ................. 2

B. Flux Rat1o at a Boundary ...................4

C. Stablitty Issues .................... 7

D. Models for Intarface Motion and Pond Parformance........ g

E. Hoat Extraction ...................... II

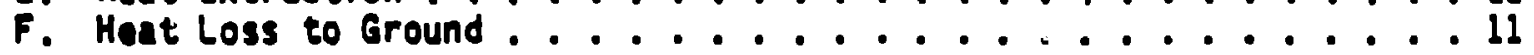

11I. HYPOTHESIS ANO DESCRIPTION OF THE DYMAMIC

PERFORMANCE MODEL ...................... 12

IY. DESCRIPTION OF EXPERIMENTS .................. 15

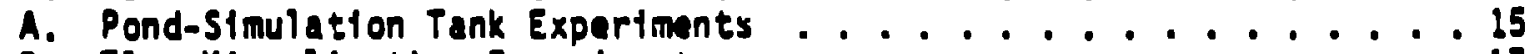

B. Flow Vtsualization Exportmants .................. 17

C. Full-sized Experimental Salt-Gradient

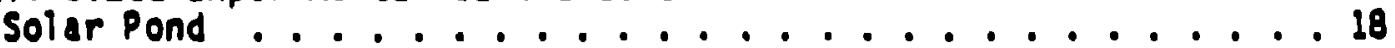

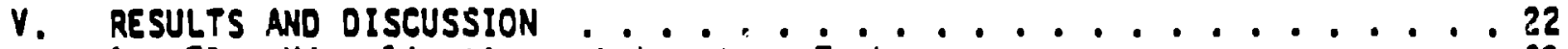

A. Flow Vtsuallzatiun - Laboratery Tank ............. 22

B. Jynamic Porformance Code Validation .............. 22

C. Solar Pond Rosults .................... 28

VI. CONCLUSIONS NO RECOMMENDATIONS FOR FUTURE RESEARCH . . . . . . . 46

VII. OISPOSITION OF EXPERIMENTAL EqUIPNENT ............... 4 ?

ACKNOWLEGMENTS . . . . . . . . . . . . . . . . . 47

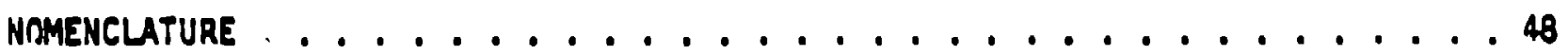

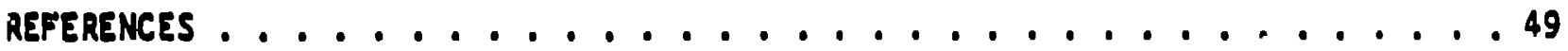


SOLAR POND RESEARCH AT THE LOS ALAMOS IMTIOMAL LABORATORY

by

G. F. Jones, R. A. Mayar, and J. C. Hedstrom

Los Alamos Natfonal Laboratory

Los Alanos, New Maxico 87545

and

D. P. Grimer

$\mathrm{Nm}$ Mext=o Solar Energy Institute

Las Cruces, New Mextco 88003

ABSTRACT

A desertption of solar pond research at Los Alamos National Laboratory is presented. The main issues in the theory of solar ponds are discussed. Among these are the Interfectal-boundaryTayur model, models for Interface metion and pond performance. heat extraction, and ground heat loss. The cere of the research effort at Los Aiamos was the development of a one-dimensional computer progran to accurately prodtct dynamic performance of a solar pond. The computer model aid the experiments that wore destgned and performed to valldate tt are described. The exportments Include two laboratory tanks wherein twaporaturg, salinitu, and plow visualization data wre obtal ned and $232 \mathrm{~m}^{2}$ outdoor solar pond. Results from prellnilnary validaticn sirow gond agreement betwen the pond's prodicted dynamic behavior and that which actually occurred in the experfwents. Mors validation using data from full-81 zed solar ponds is needed. A now correlation for the ratio of intarfactal salt-flux to heat-flux is proposed,

$$
\frac{\rho C_{\rho} \mathrm{DF}}{a F_{h}}=0.1455 \mathrm{~F}_{h}^{-0.13} \text {. }
$$

which agress wall with our data. Recommendations for Puture researeh are given. 


\section{PROGRAM DESCRIPTION}

The objective of the solar pond research program at Los Alamos was to obtain a thorough undarstanding of pond flutd dynamics. To this end, a coordinated expertmental, analytical, and numerical progran was planned. At the heart of the program was the development of a one-dimenstonal computer model capable of accurately predicting time-dependent solar pond temperatures, salinities, and interface motion.

When the program began, a major unsolved problem in salt-gradient solar ponds was the lack of a basic understending of the mechanisos by which the vartous layer boundarles wove and how to control thear. io obtaln a better understanding of layer motion, a serfes of flow-visualization experiments was concelved and performed. Two laboratory experiments and a full-scale outdoor solar pond were designed and butlt to provide quantitative data by which we could valldate the model and enhance our undarstanding of pond dynamic behavior.

11. THE THEORY OF SOLAR PONDS

A. Interfactal Boundary Layer Model

The effuctiveness of a soiar pond is determined to a large extent by the thickness of the layers. The upper cenvecting zone (UCZ) absorbs solar radiation (Refs. 1, 2, and 3) but contributes rio resistance to heat loss from the warm lower convective zone (LCZ); It is, therefore, desirable to minialze lts thickness. The diffusive core (gradtent zone) provides the pond's insuiation, aild reductions in its thickness below an optimal valie will result in increased heat-ioss rates. The thickness of the LCZ deteruitnes the amount of energy storage in the pond.

It is gonerally recognized that the bcundarles soparating the ofxed (convective) zonas and the diffustve core are not stationary, but wove in response to forces acting on then. For reasons that are explained below, when there is an finialance betwen the offects of convective stirring in the infed zones and the diffusive flux of salt and heat through the cora, the mixed zones can encroach upon the cera, reducing its thickness and decreasing pond performance. The mottons described here occur even though the diffusive core itself is hydrodynamically stable.

The physical process that governs interfactal motion in the ragion of the boundary between the LCZ and core in solar ponds is double-diffustre convection. This process also occurs at the interface separating the UCZ and the core, but may not be the major process in action. There, in addition to the effects of double- 
diffusive convertion, we encounter wind-induced convection and turbulence and offects caused by diurnal heating and cooling resulting in entralnuent of the UCZ into the diffusive core.

Double-diffusive convection may occur in any fiutd with the following characteristics: the fluid is composed of at least two spectes with different molecuiar diffusivities; and the species ake opposing contributions to density. Here, the ratio of the themal diffusivity to salt diffusivity is about 80 . A good overview of ongolng research in the area of double-diffusive convection is presented by Huppert and Turner (Ref. 4 ).

The oceanographic community has done extelisive work in the area of doubledf ifusive convection in therwohaline systems. Instead of the three-zone systed of Interest to solar pond researchers, the system studfed by oceanograph.srs conststs of two convective zones separated by an interface across which exist step changes in sailnfty and temperature. The interface varies in thickness from a few millimeters to about five centimeters (Refs. 5 and 6). Thicker interfaces exhibit a nonconvecting core (in which molecular diffusion doml nates) separated from convecting zones by regions of intermittent turbulent fluctuations. We regard these fluctuating regions as interface-boundary layers. Researchers have obtained empirical relations for fluxes of salt and heat through the interface as a function of the salintty and temperature steps across the interface.

A simple mechantitic model of the interfacial boundary layers of interest to oceanographers in which salt and heat transport are driven by themally induced convection has beer proposed independentiy by Lindberg and Haberstroh (Ref. 7) and Lindan and Skirteliffe (Ref. 8). The model assumas the simultaneous growth of a thermal boundary layer and a sailnt ty boundary layer from a sharp interface (soparating the intermfttently turbulent LCZ and the dfffusive core) into the LCZ. The steps of the model are dep? cted in F1g. 1. As time increases from zero, the thermal-boundary layer outdistances the salinity-boundary layer because the molecular diffusivity for heat is greatei then that for salt. The growth of the boundary layers into the LCZ at t1me at is shown in F1g. 1. The density distribcition within most of the thermal layer is unstable, and at some thickness $\Delta x$ occurring at time t*, the layer will break down and release a buoyant element. Subsequent turbuient mixing caused by this phenomenon restores local unfformity to the LCZ and the process of boundary-layer growth and breakdown continues in a perlodic manner. The released element, which is called a plume or "thermal" (Ref. 9), is cooler and less salty than the bulk of the LCZ and gives rise to the 
turbulent mixing within the LCZ. During the boundary-layer growth part of the process, as the boundary layers thicken, mass and energy conservation require that salt and heat pass into the diffusive core where they are transported upwards by diffusion. If we assume complete mixing of both boundary layers into the LCZ at the time of layer breakdown (Ref. 10), the ratto of the increase in potential energy of the system (caused by an increase in the elevation of salt mass) to the thermal energy transported through the interface may be estinated. This leads to a unique ratio of salt flux to heat flux (flux ratto). Oceanographic-model predictions of ehts ratto are in relatively good agrsement wh th laboratory-measured values. The flux ratio is very important for two reasons: it plays a major role in predicting pond laytr migration; it is also the correlating parameter used in the dynamic performance model described in th's report.
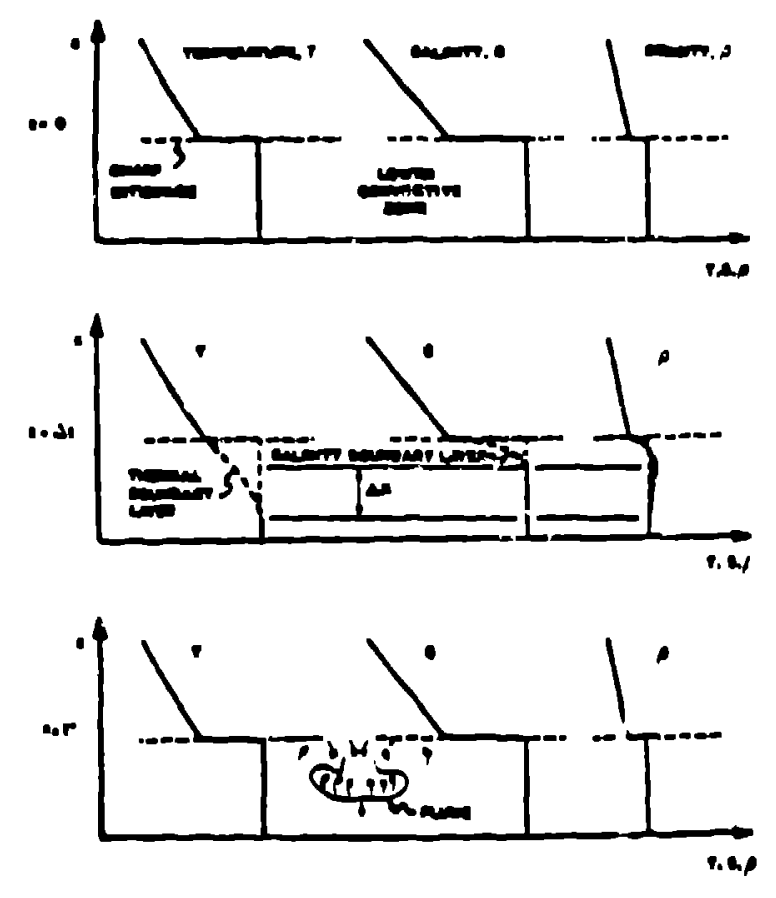

Fig. 1. Boundary layer model of double-difiusive convection of sait and heat.

\section{B. Flux Ratio at a Boundary}

Paramount among the assumptions made in the study of the oceanographic interface is that of quast-equilibrium; at any instant in time, the properties of convection are the same that would be observed in steady state with the same vaides 
of the flow parameters present at that time. Salt and heat storage effects in the interface regtons and the core are thus neglected.

Turner (Ref. 11) has shown, through the use of dimenstonal arguments, that the flux ratio depends only on a quantl ty defined as the density-stabllity ratio, $R_{p}$, where

$$
R_{p}=\frac{8 \Delta S}{a \Delta t}
$$

where $\Delta S$ and $\Delta T$ are the step changes in salinity and temperature, respectively across the boundary. In particular. for $R_{D} ; 2$, experimental evidence shows that the flux ratio decreases sharply with increasing $R_{D}$ and for $R_{p} ; 2$, the ratio is a constant equal to

$$
\frac{D C_{p} B F_{s}}{\sigma_{h}}=\left(\frac{k_{s}}{k_{t}}\right)^{1 / 2} \text {. }
$$

where, for thermohaline systems, the right side is about 0.11 . Plecewtse-1inear curve fits to data that support tha extstence of two distinct Rp regines for the oceanographic boundary are prosenteci in fig. 2 (Ref. 11).

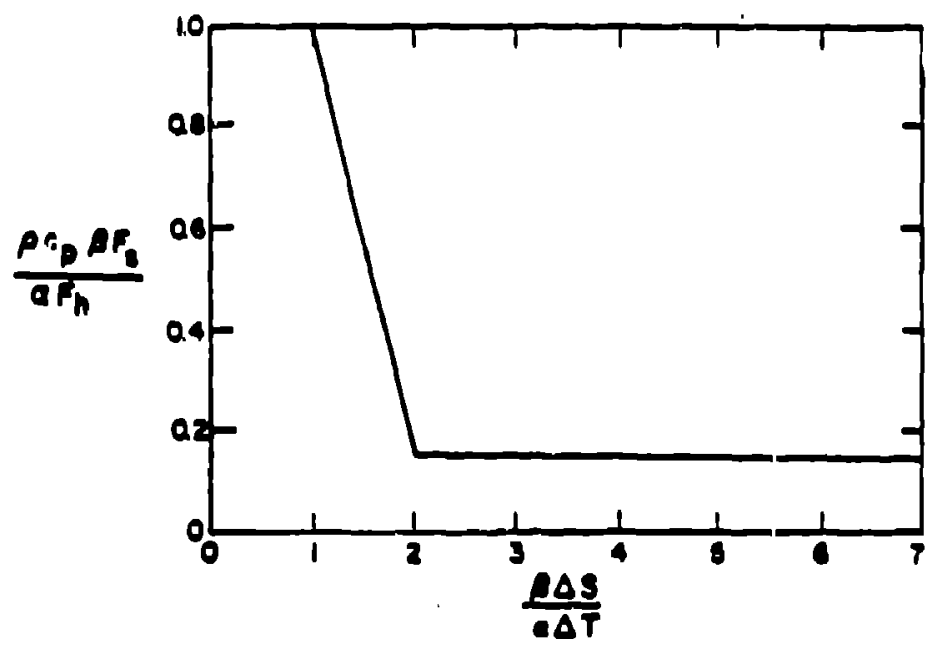

Fig. 2. Flux ratio vs Ro plecewise-linear fits from experimental data.

The regime for $R_{0} ; 2$ is characterized by entralnment aeross the interface caused by wave motion and increased transport area. For the region $R_{D}>2$, double diffustue convection predominates. Inierfaces in this regima are called diffusive interfaces. Fyplealiy, the interfaces in solar ponds jre dlffustug interfaces. 
Equation (1) is also obcained by Turner (Ref. 12) and Linden and Shirtelfffe (Ref. 8), both of whom assumed the condition of marginal stability $\left(R_{p}=1\right)$ at the location where the step change in salfntty and temperature occur. Experimental data of Maruarino and Caldwell (Rer. 6) and Crapper (Rer. 5) confirm the flux ratfo expressed by Eq. (1) for high heat flux (greater than what would be encountered in solar ponds) but indicate an increased ratio for lower heat fluxes that is not predicted from Eq. (1). Newell and Von Driska (Ref. 13) and Newell (Ref. 14) have obtatned the same result for the range of heat flux typlcal to solar ponds.

Mancint, et al. (Ref. 15) and l.indberg and Haberstroh (Ref. 7) both obtained the ralationship

$$
\frac{\Delta C_{p} \Delta F_{s}}{a_{h}} \cdot\left(\frac{B \Delta S}{a \Delta T}\right)_{\text {interface }}\left(\frac{K s}{K_{t}}\right)^{1 / 2} \text {. }
$$

which for the case of marginal stablitity at the interface reduces to the result of Eq. (1). Equation (2) indicates an increase in the flux ratio as the densitystability ratto at the interface increases. We note that in most of our experimenis, 1 well-defined interface was visible, presumably caused by a change in the index of refraction. This evidence suggests an overstable interface $\left(R_{0}>1\right)$ and from Eq. (2), flux ratios are greater than 0.11 .

As discussed by Meyer (Ref. 16), because the heat flux in a solar pond is determined to a large extent by the large thermal resistance of the thick diffusive core, the small thermal resistances across the interfacial boundary layers are not Important. Measurement of heat flux through oceanographic interfaces was performed by Marmartino and Caldwe11, Linden and Shirteliff, and Turner (Ref. 11). One result is notable, however. The usual representation of heat flux across an interface is the ratlo of the actual heat flux to that which would occur across a thin. impermeable plane placed at the same location as the interface whlle maintainting the same temperature difference across $1 t$. Turner's results indicated that for $R_{p} ; 2$, the interfacial heat flux is smaller then its solid-plane value. He concludes that for this rogime when the stablitzing salinity gradient impedes the flow of heat, a constant fraction of the potential energy releesed by the interfactal heat transport is used to trallsport salt upwards through the interface. This resul: supports the mechanistic boundary layer model of Lindberg and Haberstroh, and Linden and Shirteliffe. 


\section{Stabllity Issues}

The 1ssue of stab111ty in thermohal ine columns was considered for the case of Initfal Iinear gradtents in salt and temperature by Wetnberger (Ref. 17), Veronts (Refs. 18 and 19) and Balnes and G111 (Ref. 20) Stabllity within the core requires that not only the condition of static stablilty,

$$
\frac{d \rho}{d x}<0
$$

be sattsfled, but the wore stringent requil rement of dynanc stability,

$$
\left(v+k_{t}\right) a \frac{\partial T}{\partial x}+\left(v+k_{s}\right) B \frac{\partial 0_{s}}{\partial x} \geq 0
$$

must also be satisfled there.

Instabliftes in the core caused by infinitesimal disturbances occur first as overstable oscillatory mottons (wind-induced wave motion in UCZ and thermal expanston effects are two examples of perturbations that cause infinitestal disturbances). In system where the temperature and saitnity are increasing downward, 1f a flutd particle is dispiaced an infinitesimal distance upward to a cooler. less-saline regton, it will lose heat and salt by diffuston. Because of the large difference in diffusivities, it will cool rapidly, become more dense and be driven downward by tts body force. Should viscosity effects be insuffictent to dissipate the kinetic energy of this motion, the particle overshoots its equilibrium position and is directed back upward. This action can develop into a growing osclliation that loads to convection.

Stabllity of the core in the ragton of inclined side-wall boundaries has recelved little attention in the past. In the thermohaline case, a salt gradient must be zero at the Impermeable side wall. Lateral density gradients within the core are formed near the wells that tend to drive the otherwise stable core flutd up at the walls (Ref. 21) and outward toward the canter of the core. A system of Interleaving convecting and nonconvecting layers is formed (Ref. 22). Disturbances from this motion could lead to the generation of locill convective cells within the diffusive core and, thus, reduce lts insulating value by incroising the rate of salt and heat transport upward. 
Osctllatory motions within the core have been reported by Almanza and Bryant (Ref. 23) tho conjectured that the wotions result from overstable osctilations predicted fran double-diffusive convection theory. Initernal wave motion in the mixed zones at the incerfaces between the mixed zones and the diffusive core in sall laboratory tanks was noted by Grimmer and Jones (Ref. 24). The origin of this motion appears to result from the interwittent release of plumes predicted by the mechantstic convectlve breakdown model described above. However, disturbances did not affect the main body of the diffusive core because no convection was datected in it.

As discussed by Newell (Ref. 14), solar ponds operate at rather large values of $R_{p}(>7)$, where $R_{p}$ is the same as defined for thin interfaces. $R_{p}$ defined in this manner may not be significant in solar ponds if nonlinear temperature or salinity gradients are present in the diffusive core because Eq. (4) shows that it is the local gradients (not those averaged over the core) that control stabflity and this interface motion. Nonlinear salinity gradients in solar ponds and 1 aboratory experiments are common and have been reported by Nielsen (Ref3. 25 and 26) and Zangrando and Green (Ref. 27).

The existence of nonlinear gradients viclates the quasi-equilibrium assumption made in the study of the oceanographic interface. In particular, a nonlinear salinity gradient indicates an imbalance between the rate of salt transport across the interfaces by double-dfffusive convection and that transported through the core by molecular diffusion. In particular, if excess salt transport through the interface separating the $L C Z$ and the diffusive core continues in time, the interface region becomes unstable and overturrs. The overturnting motfon entrains some of the excess salt in thie LCZ, restores stablitity to thie interface, and results in encroachment of the LCZ upon the diffusive core. In this case, the interface is no longer in quast-equilfbrtum, but is dynamic. The mechantstic argunents presented here are a first step in explainting the reduced flux ratios at increased heat fluxes as reported by Marmarino and Caldwe11, Crapper (Ref. 5), Newe11, and Newell and Von Orisixa. Thus, for a dynamic Interface, the entralnment of excess sait stored above the boundary layers into the growing LCZ in combination with the nearconstant rate of heat transport through the core causes a reduced ratto of the salt flux to heat flux. Thls effect should become more pronounced as the tcinperature gradinnt with its destabilizing effect is increased. 


\section{Models for Interface Motion and Pond Performances}

Models for the dynamic motion of the interfaces in solar ponds have been proposed by Bergman et a1. (Ref. 28) and by Meyer (Ref. 16). The former employs Intagral methods to solve for the temperature distribution and rates of mixed-layer growth but neglects the transport of salt across the Interfaces and its effect on the reduced stablifty of the pond. The differences between predicted results and experimental data for salinity, temperature, and layer thicknesses were 20-30\%.

Meyer (Ref. 16) presents a numerical model that uses eupfrical flux-ratios to predict time-dependent salinity and temperature, and Interface motion. Prelitminary attempts at validating the model showed good agreement between experimental and numerical results. Meyer included wind-driven turbulent entrainment in the UCZ based on the work of Crapper (Ref. 29) and Turner (Ref. 30). A study of the tople of wind-driven mixing in the UCZ in the absence of double diffusive convecticn at the core/UCZ boundary was presented by Atkinson and Harleman (Ref. 31). The1r results indicated a possible reduction in annual average LCZ temperature of about 25 when wind-mixing effects occur.

A numertcal model to predict the dynamlc performance of the UCz in solar ponds was presented by Cha, et al. (Ref. 32). Several analyses of solar pond thermal performance have been performed based on stationary interface boundartes -- notably by Kool (Refs. 33 and 34), and by Hull (Ref. 35) for a pond whoze bot,tom reflects dfffusely. Among the numertcal models developed under the assumption of stationary Interface boundarles are those by Hull (Ref. 36), and Shah, et al. (Ref. 37); several solar pond design procedures are in this general category (Refs. 38 and 39). We note that results from models that consider only thermal behavior may bo adequate for small time periods (say, a few days) over which little boundary-layer motion occurs but not for large time perlods over which significant boundary. layer motion may exist.

The issue of interfactal stab!11ty in large-scale soiar ponds was addressed by Newell and Boekm (Ref. 40). Based on 1 imited experimental data they determined a criterion for stable interfaces as

$$
\frac{\Delta S}{\Delta T} \geq 3.98 \times 10^{-3} \frac{w t g}{c} .
$$


Equation (5) is expressed as the ratto of the salinity gradient to the camperature gradtent based on linear proftles of both.

Mielsen (Refs. 41 and 42) presented the criterion.

$$
\frac{G}{G_{C}^{1.6}} \leq 5 \times 10^{-3}
$$

where $G_{T}$ is the tomperature gradient $\left({ }^{\circ} \mathrm{C} / \mathrm{m}\right)$ and $G_{C}$ is the sallalty gradient $\left(\mathrm{kg} / \mathrm{m}^{4}\right)$. Equation (6) may be written in torms of the dimensionless flux ratio as

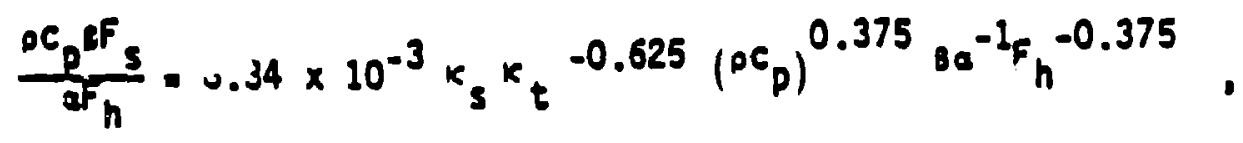

where $F_{h}$ is the heat flux $\left(W / \mathrm{cm}^{2}\right)$. For $20 \%$ ty weight NaCl at $60^{\circ} \mathrm{C}, \mathrm{Eq} .(7 \mathrm{a})$ becomes

$$
\frac{P C_{p} B F_{s}}{F_{h}}=0.0163 F_{h}^{-0.375} .
$$

It is intaresting to note that Nielsen's criterion requires o salinity gradient about an ordar of magnitudo larger than that of Eq. (4).

Nielsen and Rabl (Ref. 3) ferformad a theoretical analysts to predict the threshold value of the dally heat absorbed in the LCZ necessary for LCZ growth. They also deterimlned that the LCZ wtll shrink if the criterion

$$
a G_{T}<0.22 \Delta G_{s}
$$

is satisfied. A comparison of the above stabllity criterle with the data from the Los Alamos solar pond will be presentad in the section, Results and Oiseussion.

Research on gradient maintenance has bean performed by N10lsen (Refs. 26, 42 and 44), and by Nielsen and Rabl (Rof. 43). Thay dosertbe an injection procedure to modffy the salinfty gradtent in the region of the interface to 
malfitain a thin UCZ while miniorizing the rate of LCZ encroachaent on the diffusive core. Annual rates of salt transport in their full-scale pend were measured at $10-20 \mathrm{~kg} / \mathrm{m}^{2}$-year.

\section{E. Hat Extraction}

Heat extraction from the LCZ and heat rafection to the UCZ ill solar ponds has been studied by Jalurla (Ref. 45), and Jaiurla and ina (Ref. 46). Thair analyses indicate that core entrainment into a forced flow in a wixed zone is charactarized by the value of the overall Richardson number

$$
R 1_{0}=g \frac{\Delta 0}{\sigma_{0}} \frac{h_{0}}{\sigma_{m}^{2}}
$$

where $\Delta_{0}$ is the density difference between the wixed zone and the incorring flow, $h_{0}$ 13 the wixed zone depth, and $U_{m}$ the characteristic velocity in the mixed zone. For $R 1_{0}>0.85$ entralmant of the cora into the forced flow is negilgfble.

The experimental results of Zangrando and Green (Ref. 27) for heat extraction In a large laboratory tank show LCZ interface orosion to be greetly increased at reduced values of $R_{p}$ (deffingd at the interface) and for increased extrection velocities.

\section{F. Heat Loss to Ground}

The subject of ground conductlytty and how it affects pond performance has recelved little attention. Heat and mass transfer through solls is a complicated process that includes the effects of molecular conduction, latent heat transport by prassure-drivan vapor flow, and sensible heat transfer by the flowing liquid. Meyer and Hedstrom (Ref. 47) show conductivity to be very sensitive both to molsture (fer moisture contants of $25 x$ and less) and to soll composition (higher concentrations of sand vs. silt increase conduc: 'vity). Leboouf and Johnson (Ref. 48) show signiflcant effects of soll composition on the average annual LC2 temperature of a iarge pond. They 1ndicate the need for more data on fundamental thermal-transport properties of solls before heat and mass transfor in solls can be adequately predicted. Fundamental studies of the physles of heat and mass transfer in s011s has been done by deVries (Raf. 49) and Walker, et al. (Ref. 50). 
III. HYPOTHESIS AMD DESCRIPTION OF THE DYMMIC PERFORMANE MOOEL

The prinary thrust of the Los Alamos research effort in solar ponds is toward undurstanding the fluld dynamics and heat transfor within such ponds. To help accomplish this, a numertcal model was developed to solve the one-dimensfonal, time-dependent diffuston equations for salt and heat transport in the pond.

For heat transport we have

$$
\partial c_{p} \frac{\partial T}{\partial t}=\frac{\partial}{\partial x}\left[k_{t} \frac{\partial T}{\partial x}\right]+q(x, t)-L(x, t) .
$$

For salt transport, the governing equation is

$$
\frac{\partial \rho_{s}}{\partial t}=\frac{\partial}{\partial x}\left\{K_{s} \frac{\partial \rho_{s}}{\partial x}+K_{s t} \frac{\partial T}{\partial x}\right\} \text {. }
$$

The second term on the right side of Eq. (11) is the Sorat term; tt accounts for the trarsport of salt attributable to a temperature gradient. Kgt is the Soret dfffusion coefficient. We use values of the Sorot coeffictent given by Rothmeyar (Ref. 51). In the diffustve core, the nolecular diffusivity is used in Eas. (10) and (11), whereas an eddy diffustvity is used if the reglon is convecting. The value of the eddy diffusivity chosen is large enough to ensure complete rixing. Salintty chinges caused by evaporation and precipltation are not included in the model at present.

Our hypothesis is that boundary-layer behavior, such as that deseribed in the theory section of the ruport, extsts in ponds in the reglons of the linterfaces batwen the mixed zones and the diffusive core. We hypothestze that the beundary layers above and below a dffusive core are two halves of the thin interface layer that oceurs at the tomperature and salintty stap of intarest to oceanographers. Support for this confecture comes from the observations of plumes descending from the LCZ boundary layer regton in our laboratory-tank stmilattons of solar ponds (Ref. 52 and Fig. 5). Furthormore, w spoculate that the flux ralations obtalned across the thin interface of the oceanographic studlas also apply across a boundary layer soparating the alxed zonas and the core in solar ponds.

Consistent with the above hypothests, static and dynamic stabllit; criterla also apply. In our model, if Eq. (4) is not satisfied in a portion of the diffustue core, that portion is flagged as convecting and the appropilate addy diffusivity is 
used. If Ea. (3) is not satt sffed across a boundary between a convecting region and the diffusive core, the convecting regton enerosehes on the core. The interface stablitty erfterion, Eq. (3), is the sane as that assumed by Turnar (Ref. 12) in his analysts of a stable salinity gradient heated from below.

As discussed by Meyer (Rof. 16i), because the major thermal reststance in the solar pond is that assoctated with the diffusive core, a correlation, such as that proposed by Marmarino and Caldwil for the interfactal hat flux driven by doublediffusive convection at the interfaces, is not noeded. The heat flux is calculated frem the ofxed-zone temporatures and the core thickness.

The salt fiux across an interface is rolated to the heat flux by an expression of the form.

$$
\frac{\partial c_{p} \Delta F_{s}}{F_{h}}-f\left(F_{h}\right)
$$

where, in keeping with our hypothesis, the right stde is the same empirical on relation that is ebtained from flux measurements across a thin interface.

We belleve that Eq. (12) applles across the solar pond beundary layers because in the quast-equilibrium oceanographic studies, the flux ratio that is valid across the entire interface must be equally valid across each stde of the interface and across the diffustve core separating each side. If this ware not so, the quasiequilibrium condition would be violated. We delay further validation of this hypothesis unt1l the discussion of expertmontal and calculated results.

The numarteal model includes a systom of equations that accounts for winddriven entralnment. Wind-driven entralnmint acts in conjunction with. double-diffusive convection at the boundery betwen the UCZ and the diffusive core. We correlate entrainment of the diffusive core with the effect of wind shear by the relation.

$$
U_{0} \cdot C_{1} R 1^{-n} \text {, }
$$


Where $C_{1}$ and $n$ are mptrical constants and $U^{*}$ is the frtettonal veloct ty that is directly proportional to wind speed. RI is the local Richardson number and is depined by

$$
R 1=\frac{g d^{2}}{\partial w^{2}} \frac{\partial p}{\partial x} \text {. }
$$

Where $\partial p / \partial_{x}$ is the aunst ty greatent in the diffusive core at the location where the corr and UCZ meet.

We procend to define salt and heat fluxes caused by entralnment from the Pollowing:

$$
\begin{aligned}
& F_{t_{2}}=-U_{0} p C_{p} \Delta T, \\
& F^{20}=-U^{d D^{2}} .
\end{aligned}
$$

dT and $\Delta p_{\text {g }}$ are the changes in tamperature and solute density across the boundary.

The fluxes from Eq3. (15) are superimposed on those calculated from the effect of double-diffustve convection alone. This assumption of separaie, additive contributtuns frem both th. double-dfffustive effect and the mechantcal turbulence appears to be justlffed by our observations of the rolatively rare ofxing events in doublediffustve flows (Ref. 5) and statlar observations by Turner (Ref. 30) for grid-ganeratad turbulance.

The equations in the model are solved stmul taneously by first writing them in their finte-difference forms and then solving the resulting system of linear algobraic equations by an lmpliclt method. The mosh wize used in the finite difforonce schems was one centinoter.

A more detalled deseription of the model is given in Mayer (Rof. 16). 


\section{IY. DESCRIPTION OF EXPERIMENTS}

To obtain a doeper understanding of the plutd motion 'n the region of the boundary layers and within the alxed zones of solar ponds, we designed, butit, and Instrumintad two laboratory tanks and a full-sized outdoor pond. Date from these experiments were also used to inittate validation of the dynanic performance model.

\section{A. Pond-Stmulatt on Tank Exporimants.}

The first phase of our laboratory program Involved the development of a pondsimulation tank to obtain quanti tative data for code validation. It consisted of a glass dewar, 29-cm 1.d. and 75-em deep with a bottom heater and a thermoelectrically cooled heat exchanger on top to establish the destred temperature gradtent. To stuulato a one-dimonstonal section of a solar pond it is necassary to minimize radfal heat loss. This was accomplished by using a sarles of guard heaters independent?y controlled (by dffferenstal thermocouples) that maintalned the outalde wall of the dawar at the same temperature as the fluid within. The outside surface of the guard heater assembly was insulatad with a minimum of $10 \mathrm{~cm}$-thick polystyrane Insulation.

A rake supporting two 100 -ohm platinum resistance thermometers (RTDs) and two platinum point-conductivity probes was used to measure temperature and salintty." The RTi's were glass encapsulated and had an outslde diamater of $0.8 \mathrm{~mm}$ to provide near-pofintwise temporature measurament. RTDs wore chosen for this exporiment because of that greater sensitfulty and roltabllity compared with other themomatary. RTD rc.istances were masured using a 4-wire potontlometrle circult with a high-lipedence digltal vol tunter.

itive point-conductivity probe used in the experiment described here was developed -t Los Alanos because of the need for accurate, high spatial resolution, in sity salinity masurements over a broad salinity range (Rofs. 53, 54 and 55). A schematic diagram of a point conductivity probe is shown in Fig. 3. Basicaliy, the probe conststs of a length of plati num wire $0.51 \mathrm{~mm}$ in dianater ancased in a 2-nim-o.d. glass tube to expose only the tip of the platinum wire. This asssembly

- Intefally, to datermine if any radial or circuiforantial tamperature gradients existed, we measured temporature using flve RTOs equally spaced on a rake having two horizontal, mutually parpandleular legs extending radtally to the laside wail of dewar. No signifleant temperature varlations were found. 


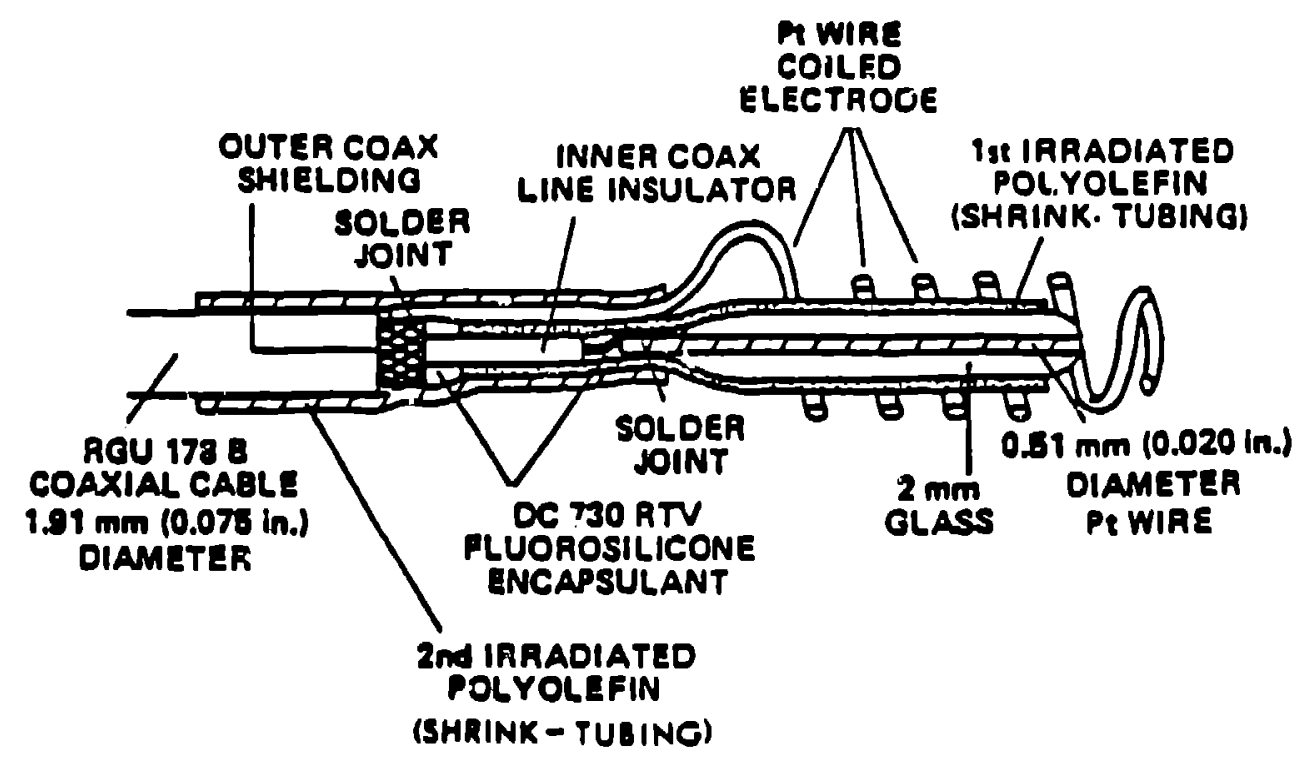

F1g. 3. Pofnt-Conductivity probe schematic diagram.

is covered with an RTV fluorsilicono that is then sealed from salt water intrusion by a length of shrink tubing. A spiral-wound secondary electrode of large surface ares surrounds the platinum tip. Point-conductivity measurments are obtained as a small electric current flows between the two electrodes. The current density at the probe tip is much grater than that at tine secondary electrode because of the large difforence in surface areas. The resulting electrical conductivity measurement 13, thus, nore heavily walghted in the reglon of the tho than elsowhere.

Before use, the plattnum probe tip was first platinized using a Beckman model PK-1A platintzing kit." The platinized coating reduces the rate of deterioration of thu exposed probe tfp and provides more stable and precise conductivity raadings.

During each experiment, the probe was caltbrated in situ by oxtracting a mintmum of four sumples from the tank. The samples were withdrawn using hypodermic needies or stainless steel eaplliary tubes at the same horizontal location as the probe tip and at the sam time the conductivity was masured. The specific gravity of each sample was then moasured (after it cooled to room temperature) by a Mohr-Hestphal belance aceurate to \pm 0.0001 .

- Beckman Instruments Inc., Cadar Grova, New Jorsey 07009. 
The rake supporting the RTDS and polint-conductivity probes was automatically driven through the tank at a preserfbed tim during the day at a rate of about $1 \mathrm{ca} /$ min. One traverse per day was taken, but in sttu callbration was performed only every three or four days to infnimize disturbing the layar by extracting and reinjecting sauples of flutd. On tha days when calloration was parformad, a salt balance was calculated for the LCZ and UCZ between that day and the day of the last calibratton, and the ayeraye salt flux through the Intorfaces es timated for that period of tfme. The heat flux was detarmined from the local slope of the teaperature proffle. Data was automattcaliy taken by a hP 9830 computer and data acquisitfon system and stored on magnatic tape for future roforance.

\section{B. Flow Visualization Experiments}

The second phase of our laboratory experimental program consistad of flowvisualization experfments afmed at a detalled understanding of the flow patterns near the boundary layers. In additfon, we al so obtal ned quantitative tomperature and salinity masurements to supplement those from the dewar experiments. Thts study was carrled out in a bottom-heated plastic tank of approximate dimensions $30 \mathrm{~cm} \times 30 \mathrm{~cm} \times 75 \mathrm{~cm}$-deep (Ref. 52). The sides and botton of the tank were insulatad. Sections of the side insulation wre removable to permit us to observe the flows and to photograph thien.

After searching for an approprlate flow-visualization technique wherofn we considered shadow graphs, dye markers (Ref. 56). and hydrogan bubbles, we decided on using thymol blue as a flutd particle tracer (Ref. 57). Thymol blue is a Ph Indicator, and suluttons containing small concentrations of tt will change color locally by the eraation of lons in the region of a charged electrode. A grid lectrode (about 10-cm square), made up of fine tungsten w1res, was suspended about lan below the LCZ interface for experiments performad in the LCZ and Immediately above the UCZ for experiments parformed in that zone.

To obtain local salintty and tamperature data, a polnt-conductivity probe and - type-T therwocouple (sultably protected from salt wator attack) were installed at the end of a long tube that was manuclly traversed through the tank. A sertos of movable extraction ports were Installed in one of the tank walls to accomodate point probe calibration. During extraction, the probe tip and the extractor port were allgned by using a cathetometor. 


\section{Full-Sized Experimental Salt-Gradiont Solar Pond}

The primary purpose of our experimental pond is to provide a mechanism for full-scale validation, under controlled but realistlc conditions, of our numerlcal model. A detafled description of the pond design and construction is given in Jones, at al. (Rof. 58) and Jones and Meyer (Ref. 59) and only a brtef summary of it is given here.

A untque feature of the pond is its excavation not from sand or clay soll, as with other ponds, but from a lightweight porous rock known as "tuff"; such rock forms the the major fraction of the Los Alamos area surface geology. Tuff has a relatively small thermal conductivity; which implies that 11ttle, if any, insulation is necessary to reduce perimeter heat losses. In addition, because tuff is relatively strong, it was possibie to butld a pond with vertical side walls and mintinize the problen of localized convection that could occur if the sidewalls sloped. Because of these features, the salt and heat transport in our pond was expected to be truly one dinanstonal.

The construction of the $232 \mathrm{~m}^{2}$ by $3.5 \mathrm{~m}$-deep pond was begun in October 1981. After excavation, the pond walls were covered with an 8 -con thick layer of polyurathane insulation, mostly to smooth the rock surface and prevent a possible ilner tear. A back-up liner of 0.5-lam-thick, ralled-on Hypalon (on the walls) and a 0.5-nia-thick shent of PYC (on the bottom) was installed aftar $15 \mathrm{~cm}$ of smooth plastar sand was spread evenly on the rock floor. Another layer of sand covered the PVC, in whtch we embedded four electric resistance leak detectors. The main liner was 1.2-mm-thick Pfter glass-retnforead Hypalon installed in three plecas and jolned in the fleld. To acconodate sottling, we delayed anchoring the edges of the main liner in the ground unt1l the pond was pllled. Six perimeter heat flux metors we installed in the tuff before beginning insulation work .- one in each wall and two in the pond ploor.

Instrumentation at the pond conststs of an underwater pyranometer (Eppley model 8-48) and traversing and fixed salintty- and temperature- measuring probes. The traversing device consists of a wheeled trolley driven vertically by a wire at a rate of $0.9 \mathrm{~cm} / \mathrm{min}$. through the pond; the trolley rides on a rectangular rafl. installed on the troliay are two platinum RTDs, an induction salinometer (Beckman CEL-RAS7 with a RiS5 indicator), and a platinum point-conductivity probe. 
Typteally, one traverse por day was run; each traverse provided temperature and salint tata at incresients of $0.8 \mathrm{~cm}$. The fixed probe consists of a rake supporting 28 type-T thermocouples and 28 sample-fluld withdrawal ports located every $10 \mathrm{~cm}$. The ports perrit in situ calfuration of the polnt probe installed on the traversing trolley. The instrumentati on rakes were stabll1zed by supports from a catwalk that extended over the pond from one of tts banks. The materfal of construction was 316 stainl ess stael nearly throughout. No welding was done on metals to be submerged In the pond and bending of materlais used for components that would be submerged was of nimized to reduce the posstbillty of accelerated corroston.

The Inftial gradient of 120 al was established on August 4, 1982. The initial LCZ and UCZ thirknesses were $120 \mathrm{~cm}$ and $20 \mathrm{~cm}$, respectively. The pond began warming rapidiy with the $L C Z$ inftially at $25^{\circ} \mathrm{C}$ and $18.5 \mathrm{~h}$ salinity. The rate of tamperature increase in the LCZ was $1.2^{\circ} \mathrm{C} /$ day for the first month of operation, decreasing te $0.25^{\circ} \mathrm{C} /$ day for the second month.

At the end of the first week in September, we began to notfce an abnormal drop in the surface level of the pond and suspected a leak. A graph of the salinity proflles over the perfod wnen the leak began is shown in Fig. 4.

In F1g. 4 ve note the thiciness of the core (gradient zone) is the same for August 31 and Septamber 21, however 1ts location 13 about $13 \mathrm{~cm}$ lower on the lator day. We see furtier evfdence from inspecting Fig. 5, where the depths of varfous isosalinity planes in the core are showr as a function of time. In Fig. 5 there is a negative slope to all curves ofter September 1. We concluded that the leak was In the LCZ. Subsaquent calculations of salt inventorles within the pond indicated a leak rate of about $1.8 \mathrm{~m}^{3} /$ day.

After cleanup of the excess salt or the bottom of the pond, removal of the catwalk and baseplate, and cooling tha pond, two divers descended to inspect the liner in the LCZ region. They found ane-cm-long hole in the crease of the linar where the north wall and the floor meet. The toar was not in a soam. We presume that the tear was caused by excessive stress during settling of the pond buttom and we Indteate below two independent offects thet may have led to the high stress in the 11 ner. First, the comblnation of hydrostattc pressure and high temperatures from large solar radfatten intensitfes on the north wall caused the back-up and ma in Hypalon lirars to sttck together. The neaded slippage of the main i1ner was thus preventad and large strasses at the bottom rasulted. A sfollar strass tear had occurred on the west wall above the waterline sometime after the ene in the LC.Z and was repalrid. Stfeking was evident along that wall also. Second, because of 
SOLAR POND

SALINITY VS DEPTH

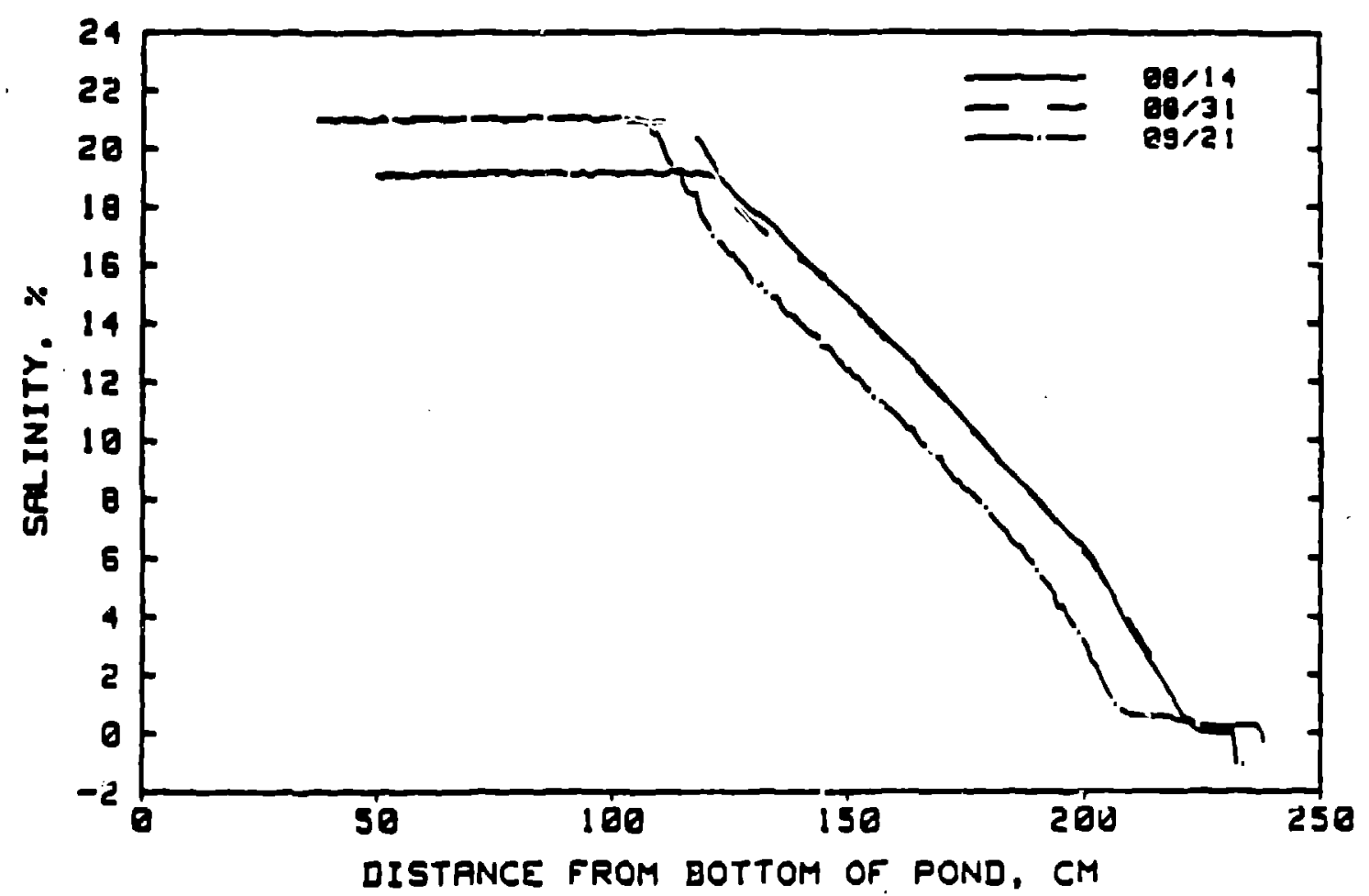

Fig. 4. Salintey proffles for solar pond.

SOLAR POND

DEPTH OF CONSTANT SALINITY

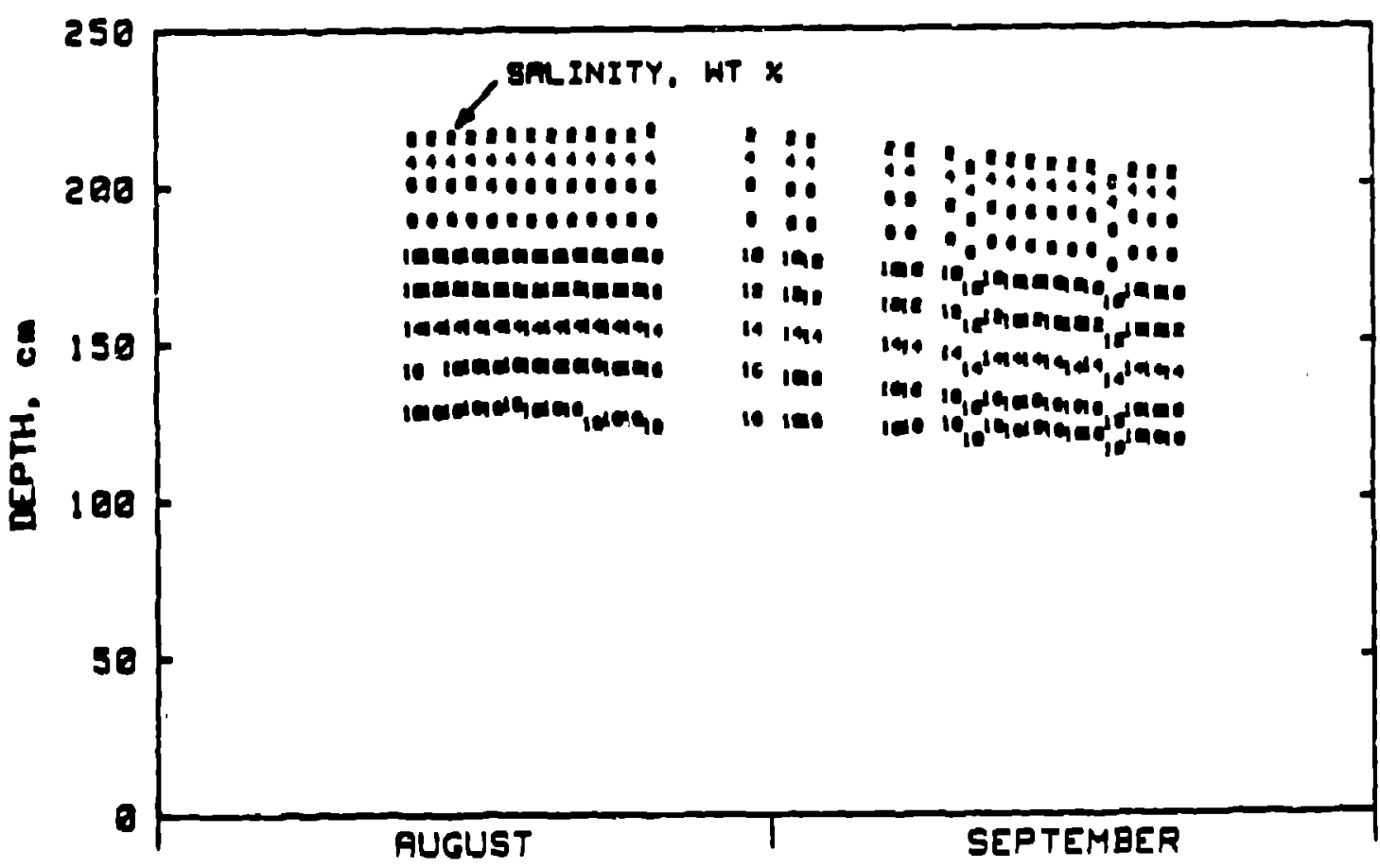

Fig. 5. Isosalinity-plane depth as a function of time. 
the harsh environment into which the Hypalon IIner was to be put, the supplier of the liner recoumended ffberglass rolnforcing for additional strangth. Polyester is the standard ref nforcement. Fiberglass, however, has very little ductillty compared with polyester. Wo belleve the lack of ductility in a region where it was needed contributed to the taar.

Aftor to attempts, the divers repalred the leak by putting two hypalon patches on it and using a "5-minute" epoxy as a bonding agent. Sandbags were placed over the repafred area as added insuranco. He arrived at the deciston to use epoxy after evaluating the results of numerous underwater patching tests performed in the laboratory.

Arother problen arose early in June 1983. For some reason, gas began to seep from the rock beneath the pond forcing the maln liner upwards toward the surface. About a dozen gas bubbles under the liner were noted ovar a 3-week perlod. Their helghts ranged froal several $\mathrm{cm}$ above the floor to one that forced the liner through the surface of the pond. All of the large bubbles were removed by pushing down on them from above and pushing then toward a cornor where a small inctsion in the liner had been made on the bank. The orfgin of the gas remains uncertain. A gas analysis showed it to be nitrogen-rich alr posstbiy displaced from the porous tuff by unusually large mountain run-off earlier in the year or from the alr displaced by the brine from the liner leak 6 months earlfer. The appenrance of the few smaller bubbles that were left in the liner has not changed since the end of June 1983.

One unfortunate result of the gas problen was another tear in the liner. It agal $n$ occurred at the base of the north wall. Rather than cooling the pond, we attempted to pateh the hole from above water. A double-sided, tar-like tape supplied to us by L. Wittenberg of the Mound Factlity, Mianisbirg, Onto, was applied to the botton of a stainless-steel plate. Aftor cleaning the pond ifner in the region of the tear with steel wool, we lowred the piate onto the araa, tamped it inte place, and placed sandbags on top of $1 t$. The water level of the pond stabll1zed after the patch was applied. 


\section{RESURTS AMD DISCUSSION}

\section{A. Flon Kisualization - Laboratory Tank}

Figure 6 shows a photographic sequence of flow patterns imediately below the Interface separating the LCZ and the diffusive core. Photographs were taken at 5 second intarvals. Plumes of cool, less salty, dyed water are clearly visible as they descend from the interface. Patterns of this type were repeatediy observed for the cases where the effects of bottom heating did not disturb the interface. A structure such as that shown in Fig. 6 agrees very well with the break-down processes assumed in the mechantstic madel.

At large rates of botton heating, the convection generated at the heating plate directly influences the flow at the interface separating the LCZ and the core. The flow patterns immediately below this interface under the condition of large bottorn heating are shown in Fig. $7(b)$. Flg. $7(a)$, which shows fluld motion below the interface with no bottom heating, is included for comparison. We note in Fig. $7(b)$ that the plume structure has been replaced by whisps of flutd being swept away by the convective stirring within the LCZ. We belfeve this influence may cause an increase in the rate of salt transport through the boundary and result in an increased flux ratio. The oceanographic model for the interface as'sumes that the convective motions in the neighborhood of the interface are caused solely by the effect of heat transport through the interface. Thus, interfacial salt and heat transport caused by convection arising from sources other than plume motion are neglected in the model.

Quanti tative measurements wh thymol blue have proved difficult. During observations made $w$ th heat fluxes in the range of 50 to $90 \mathrm{~W} / \mathrm{m}^{2}$. piume velocities ranged between 0.1 and $0.2 \mathrm{~cm} / \mathrm{s}$. The average plume veloct ty appeared to 1 ncrease with heat flus; plume spacing ranged from 3 to $5 \mathrm{~cm}$.

\section{B. Dynaric Performance Code Validation}

Our first attempt at validation was to use the numerical model to reproduce the experimental results obtained by Purdue University Investigators (Ref. 60) in a bottom-heated, solar-pond simulation experiment. Detafls of the comparison are presented in Meyer (Ref. 16). Flgures 8 and 9 compare our calculations with experimental data; agreement is good. Figure 8 indtcates that the model reproduced the motion of the interfaces very well during the time the mixed zones were advancing into the diffustve core. In Flg. 9, good agreement is also shown between the calculated and experimental temporature histortes in the mixed zones. 


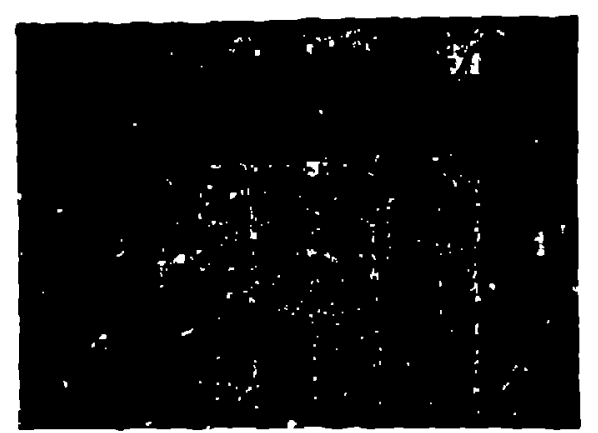

(a)

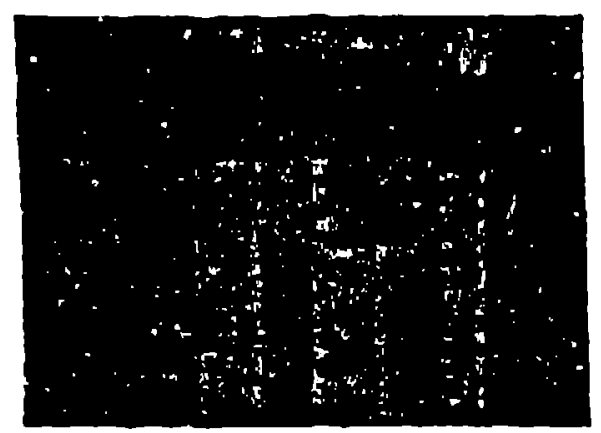

(c)

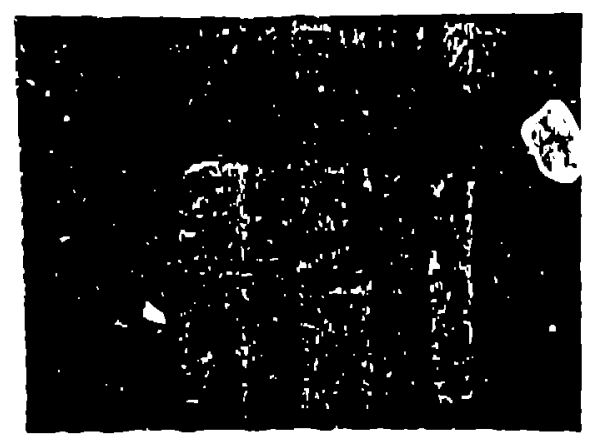

(e)

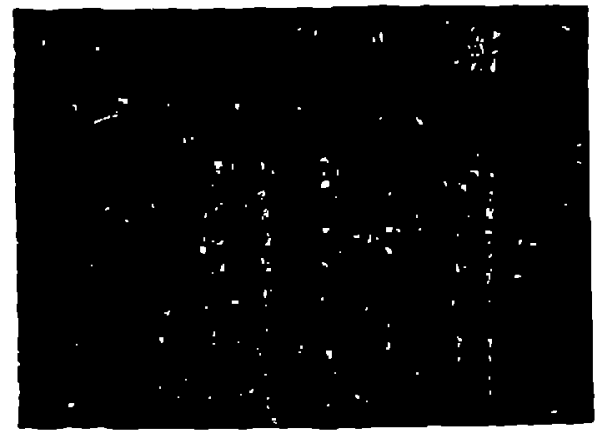

(b)

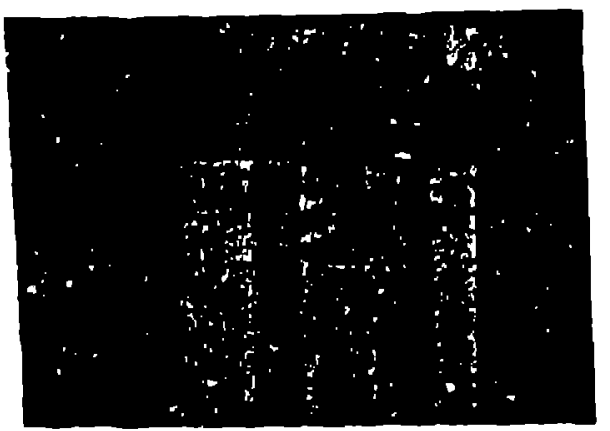

(d)

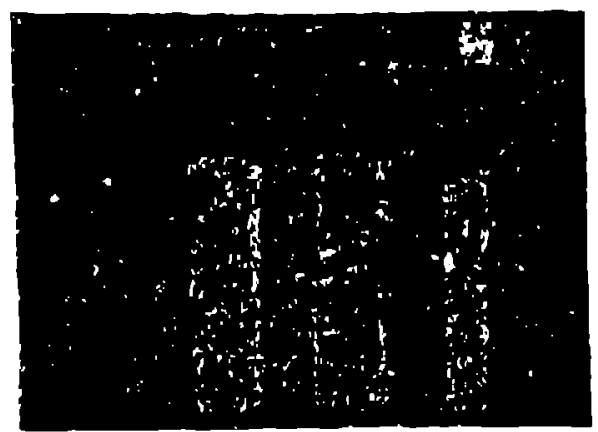

(f)

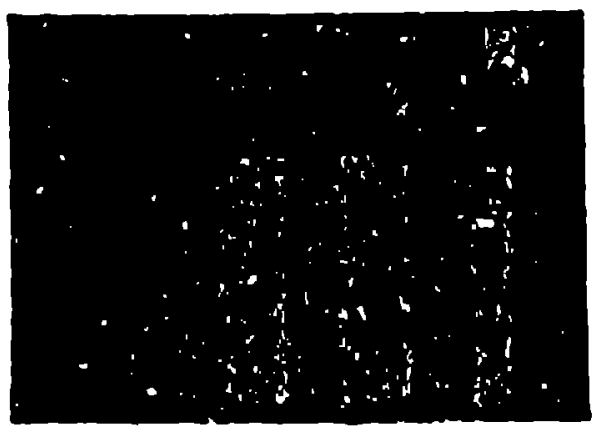

(g)

Fig. 6. Flow patterns fust below interface separating the fiffusive core and lower convective zone with small bottom neating. sequence was photographed at 5-second intervals. 


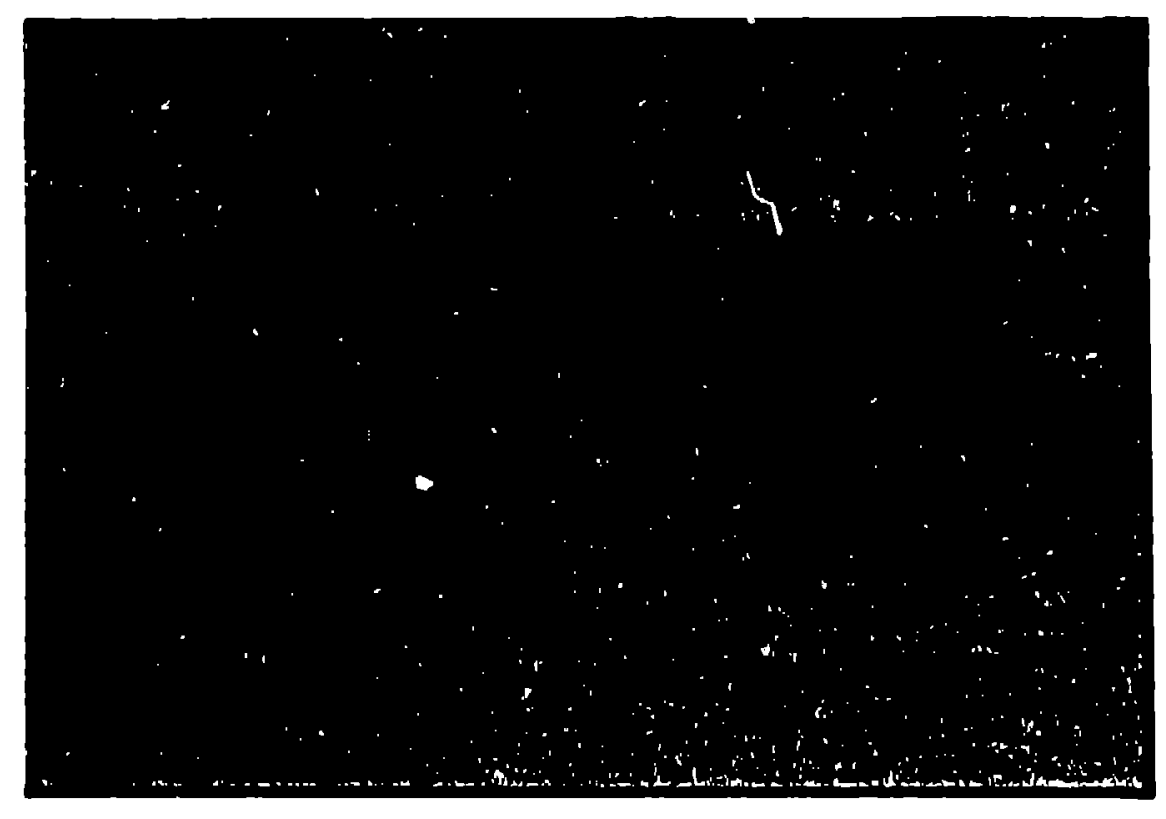

(a)

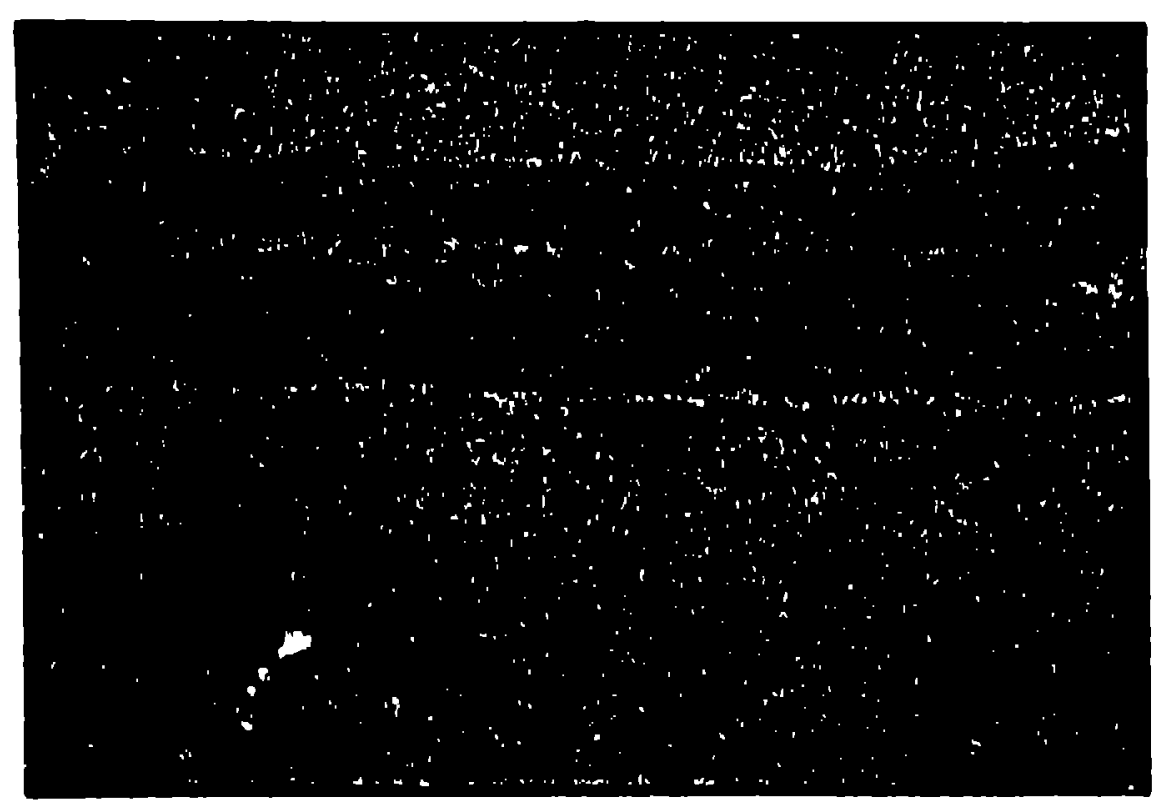

(b)

Fig. 7. Flow pattern Just below interface separating the diffustve core and lower sonvectlve zone (a) with heater uff and (b) with nacer on. 


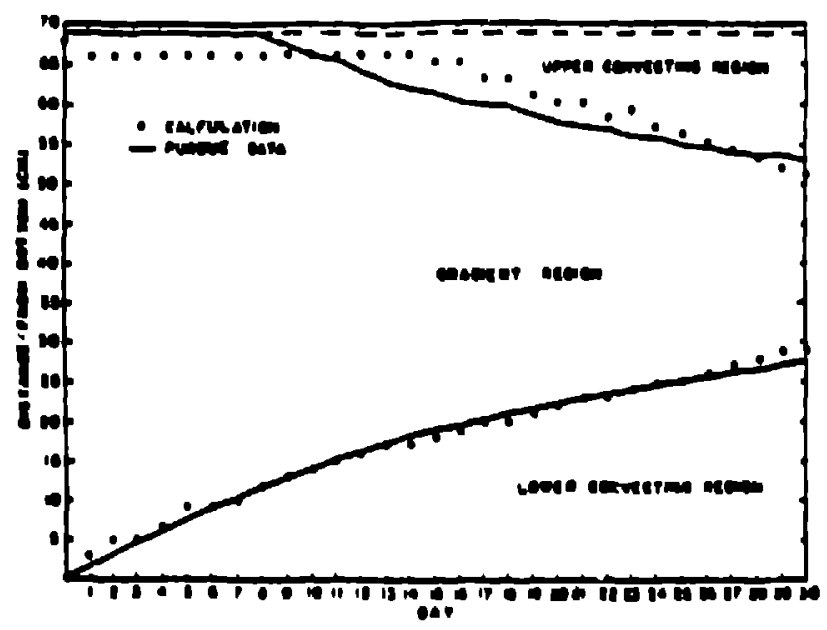

Fig. 8. Layer posittons versus time.

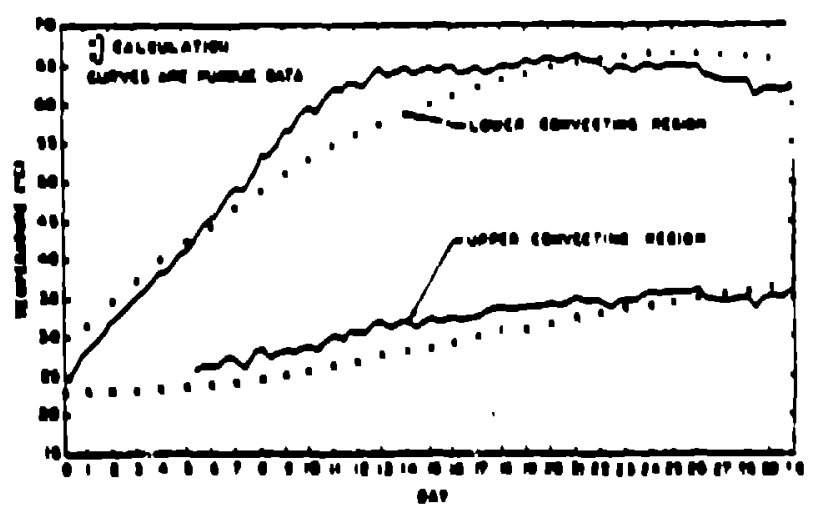

F19. 9. Convecting zone temperuture versus time.

To obtain a good match to the experimont above, it was necessary to modtfy Eq. (7b) to

$$
\frac{D c_{p} F_{g}}{d F_{h}}=0.1455 F_{h}^{-0.13} \text {. }
$$


Equation (16) gives flux ratios larger than those fron Eq. (7b) but remains within the range of Marmarino and Caldwell data and Los Alamos data yet to be presented.

We heve used our wind-entrainment, double-diffustve model [Eqs. (13) through (15)] to calculate the performance of the Mtamisburg, Ohto, solar pond over a

3-nonth perfod. Detalls of the comparison are described in Meyer et al. (Ref. 52).

There is some uncertalnty regarding the approprlate values of $C_{1}$ and $n$ in Eq. (13). We tried two sots of values in our calculations. The values of $c_{1}=$ 0.075 and $n .1$ were obtained by Hu (Ref. 61 ) and the values $c_{1}=n-3 / 2$ mere obtained by Kft, at al. (Ref. 62). Observed and calculated interface positions as a function of time are shown in F1g. 10. We note that the calculation with $n \cdot 1$ gives good agreement with observations for the UCZ and LCZ; the use of $11=3 / 2$ underestimates the growth of the UCZ.

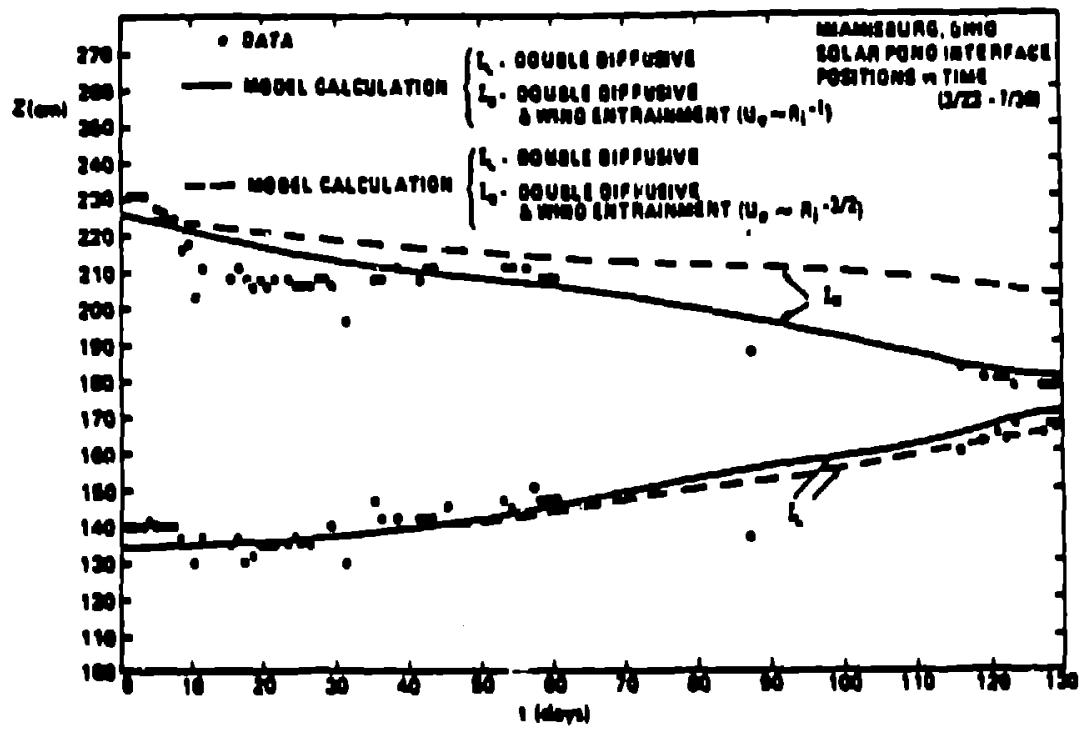

F19. 10. Comparison of the masured and calculated interface positions for the Misursburg solar pond.

The correlating perameter in the numerteal aodel is the plux ratio. The object, when comparing the calculated results frow the rodel with those from our experiments, is to calculate the flux ratto from expertiantal date and, by using this flux ratio in the coda, atteapt to match the perfomance observed in the experiment.

We obtain an expression for the time-averaged selt flux from

$$
F=-U_{1} p_{3}+x_{3} \frac{\partial p_{3}}{\partial x} \text {. }
$$


where $F$ is the mot instantaneous salt $p) u x\left(g / \mathrm{cm}^{2}-s\right)$ and $U_{1}$ is the Instantaneous boundary velocity ty $(\mathrm{cm} / \mathrm{s})$.

Equation (17) may be integrated over time from $t_{1}$ to $t_{2}$ to obtain

$$
\Delta M,=\int_{t_{1}}^{t_{2}} F d t \cdot-\int_{t_{1}}^{t_{2}} u_{1} p_{s} d t+\int_{t_{1}}^{t_{2}} x_{s} \frac{\partial p_{s}}{\partial x} d t .
$$

or

$$
\frac{\Delta M_{3}}{\Delta t}=\frac{-\bar{o}_{3}}{\Delta t} \int_{t_{1}}^{t} U_{1} d t+\overline{k_{3} \frac{\partial D_{3}}{\partial x}} \text {. }
$$

In Eq. (18), the overbear Indicates a time-averaged quantity and $M_{s}$ is the mass of salt per un it of pond area.

With

$$
U_{1}=\frac{d x}{d t}, \quad \frac{\Delta M_{s}}{\Delta t} \cdot \frac{M_{s t}-M_{s t_{2}}}{\Delta t} \text {, }
$$

Eq. (18) becomes

$$
x_{s} \frac{\overline{\partial \theta_{2}}}{\partial x} \cdot \frac{M_{s t_{1}}+\overline{\theta_{s}}\left(x_{t_{2}}-x_{t_{1}}\right)-M_{s t_{2}}}{\Delta t} .
$$

The numerator in Eq. (19) is the difference in salt inventories (per unit area) in the nixed zones at times $t_{1}$ and $t_{2}$, respectively plus a contribution from the product of the time-averaged density at the interface and the distance over which the interface moves in time at.

He use Eq. (19) to calculate salt fluxes in our experiments. The salinity values in the mixed zone are obtained from the measured densities of the extracted samples. The values of the heat fluxes are obtained from the local temperature gradients in the regt on of the interface under consideration.

- $27-$ 
Our largest souree of error was in doterwining the posttion of the interface. The sal infty-proftle data were seattered whereas the temporature proffles were smooth and roundad in the regtion of the interface. We dofined the Interface as the intarsecti on of the stralght-ilne extenston of the temperature profile in the core and the constant teriperature $11 \mathrm{me}$ of the mixed 20ne. An error range in the flux ratto arfses fram uncertainties in the location of the interface and the value of the temperature gradient. Property data is from E1wall, ot al. (Rof. 63).

A comparison of the data from the tank experiments with calculations is presentad in Figs. 11-18. Time-dependent LCZ salifilty, temperature, Interface location, and UCZ salinfty, and Interface location are shown. Notable results are sumarlzed in Table I. The duration of the experiments ranged from 12 to 22 days, and heat fluxes ranged from 8.8 to $61.2 \mathrm{~W} / \mathrm{m}^{2}$. Included on each figure are the heat flux and the dimanstonless flux ratto used in the model to produce the calculated results as shown. We note that in all cases, the hast flux and flux ratto used in the model fall within the error range of the tank data. We further note that good agreoment betweon the calculated and experfmental results is obtained by using these values.

The anomalous behavtor of the LCZ temperature history in F1g. 16 occurred whon, in error, we accidentally increased the rate of botton hoating slightly on the twelfth day of the exporiment. The discontinut ty in heating was included as input to the model for this case and Prom F1g. 16, wo note that the model predicts the correct temporatures even after the sudden change of heating rate occurred.

From the results presented in F1gs. 11-18, and the good agraement observed between calculated and predicted results, it appears that the model contains the features necessary to predict time-dependent salinity, temperature, and motion of the int xed layers.

\section{SOLAR POND RESULTS}

The 232- $\pi^{2}$ sol ar pond was operated in a run-down mode (no neat extraction or gradient malntenanes) for the perlod from June 1 to August 18, 1983. The primery purpose of the exporiment was to obtuin flux-ratio data for a full-sized pond and compare then with those data obtained from the anall-scale laboratory experiments. Because the experiment was not funded, model validation would be done oniy if sufficlent time could be spared from other projects, or if personal time could be found. 


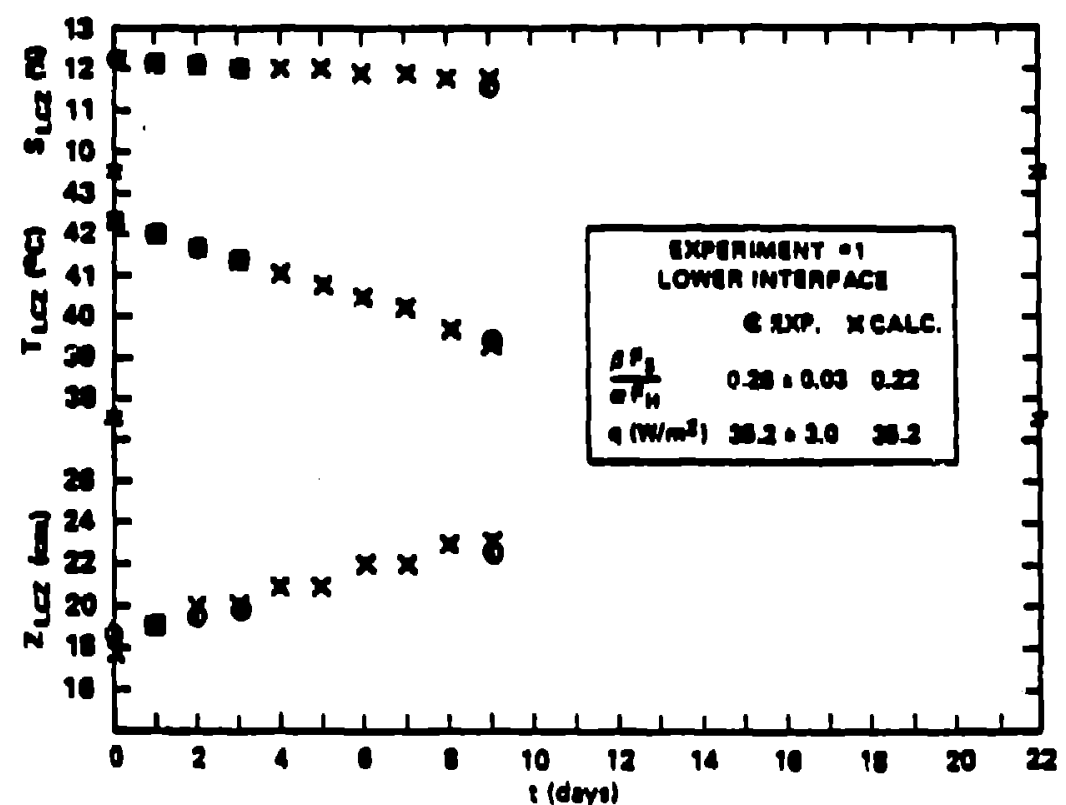

F1g. 11. Comparison of observed and calculated rasults for laboratory tank experiment number 1.2 . het ght of boundary layer above pond bottoin. $F_{H}-F_{h} / o C_{p}$.

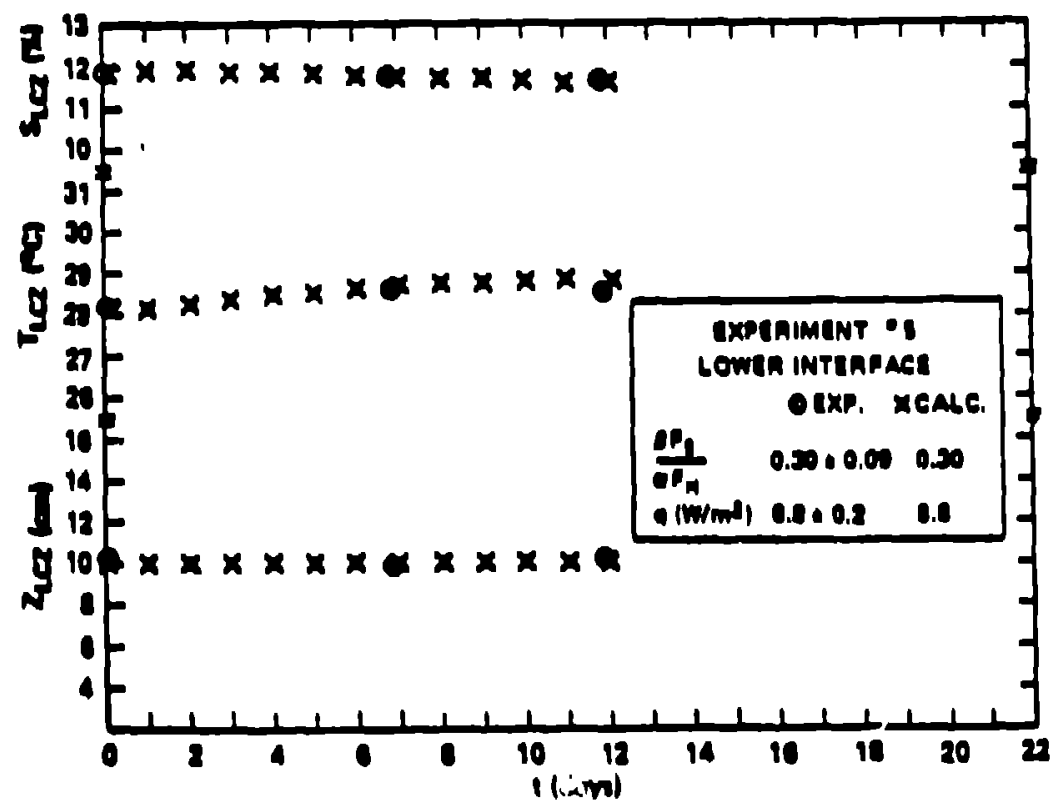

F1g. 12. Comparison of observad and calculated results for laboratory tank experiment number s. Z . height of boundary layer above pond bottom. $F_{H} \cap F_{h} / o c_{p}$. 


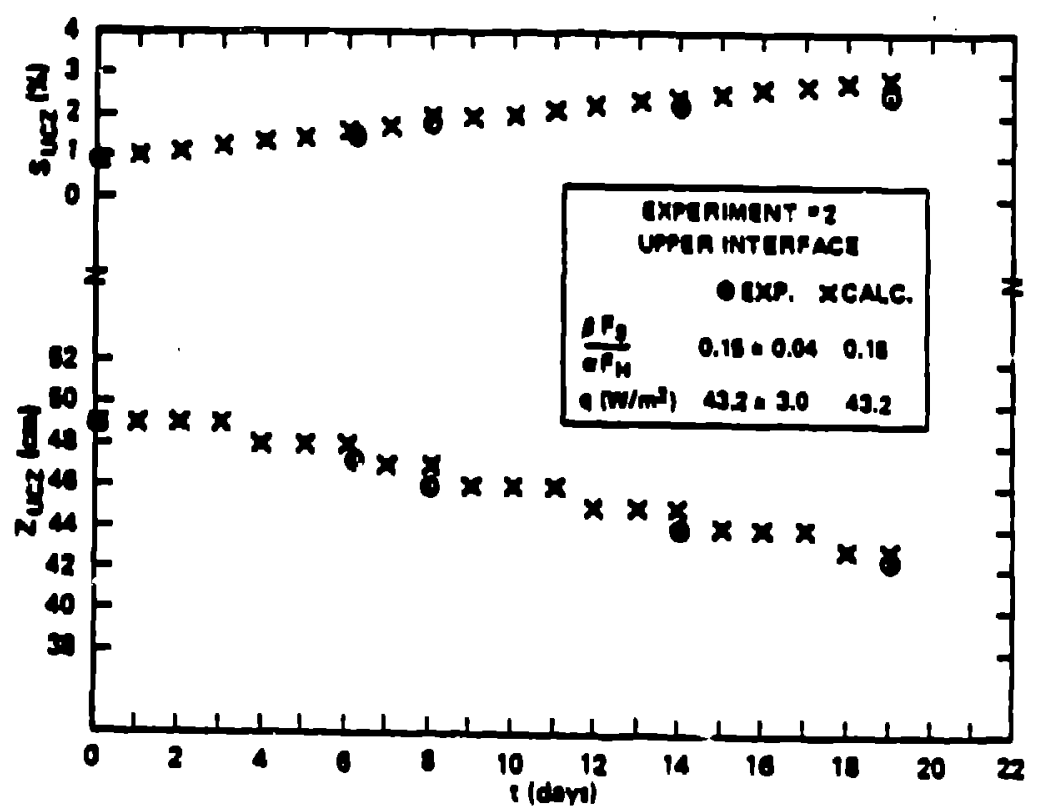

F19. 13. Comparison of observed and calculated results for laboratory tank experiment number 2. 2 . helght of boundary layer above pond buttom. $F_{H} \cdot F_{h} / o c_{p}$.

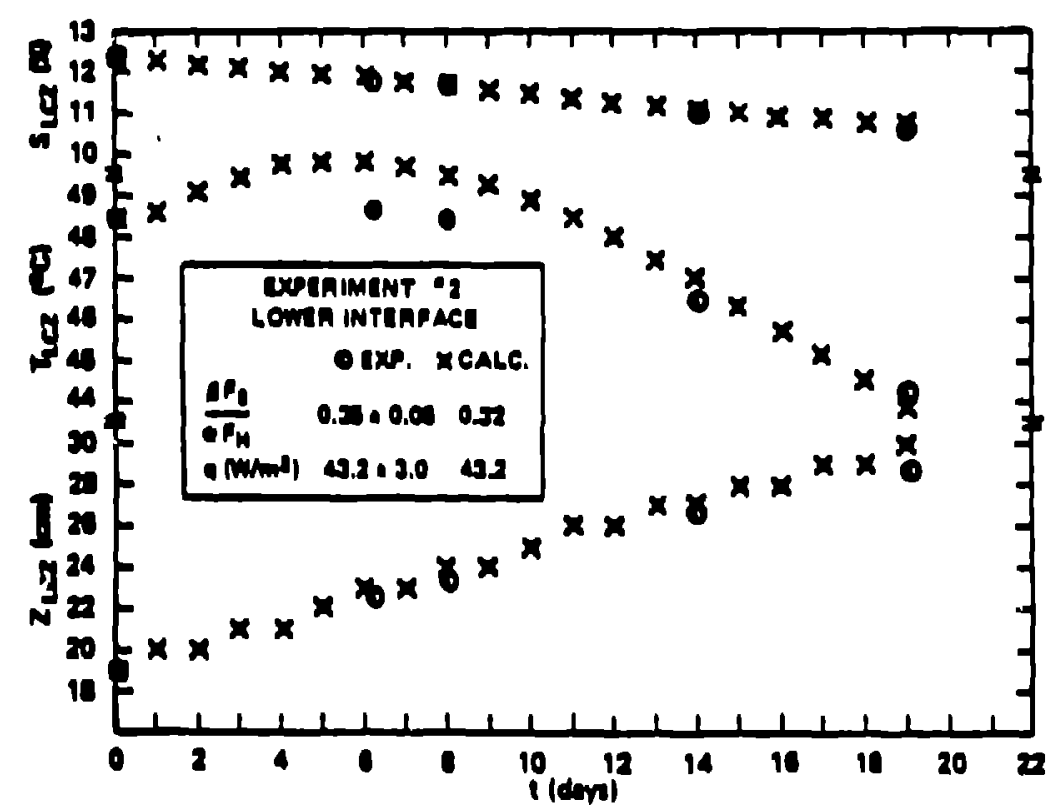

F1g. 14. Comparison of observed and calculated results for laboratory tank exporiment number 2. Z helght of boundary layer cbove pond bottom. $F_{H} \cdot F_{h} / o c_{p}$. 


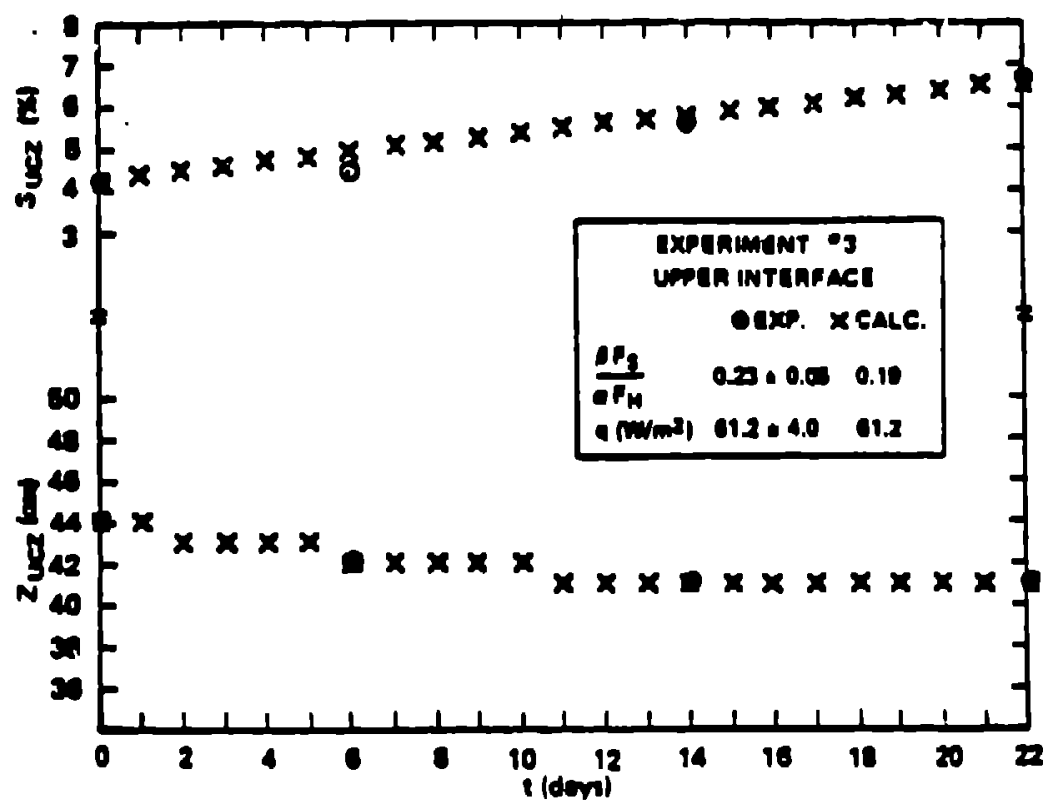

F19. 15. Comparison of observed and calculated results for laboratory tank experiment number 3 . $Z$. helght of boundary layer above pond bottom. $F_{H}=F_{h} / \rho c_{p}$.

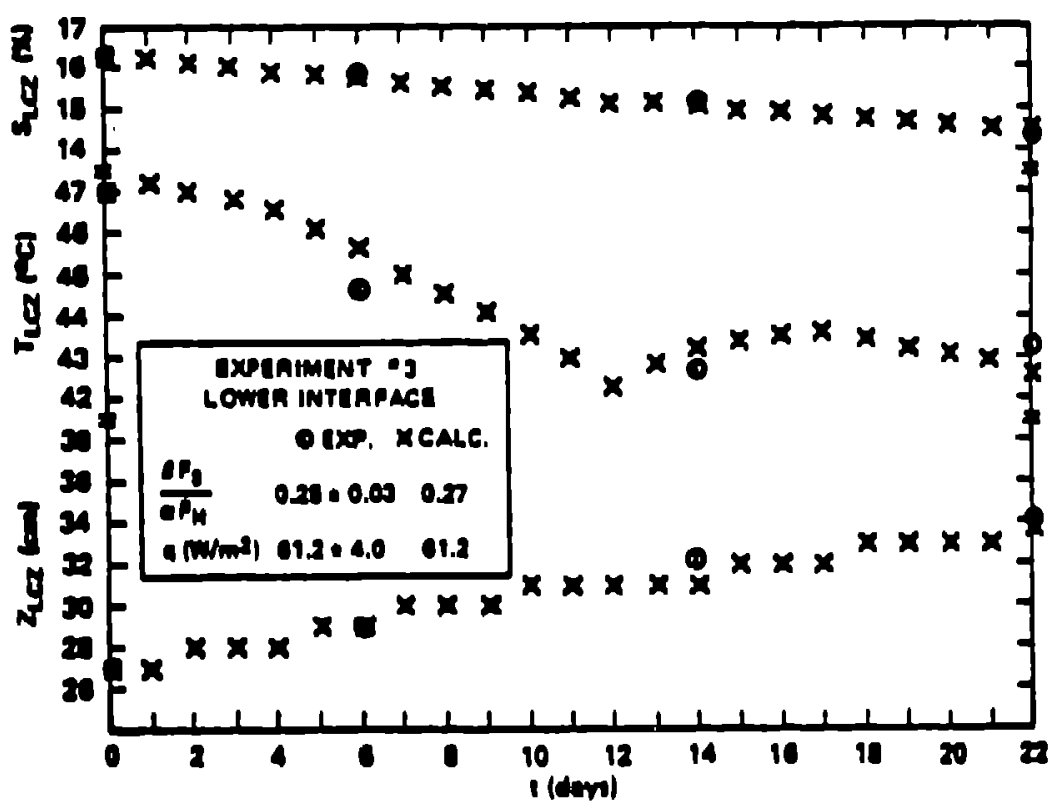

F1g. 16. Comparison of observed and calculatad results for laboratory tank expertment number 3. $Z$. hetght of boundary layer above pond bottom. $F_{H} \cdot F_{h} / o c_{p}$. 


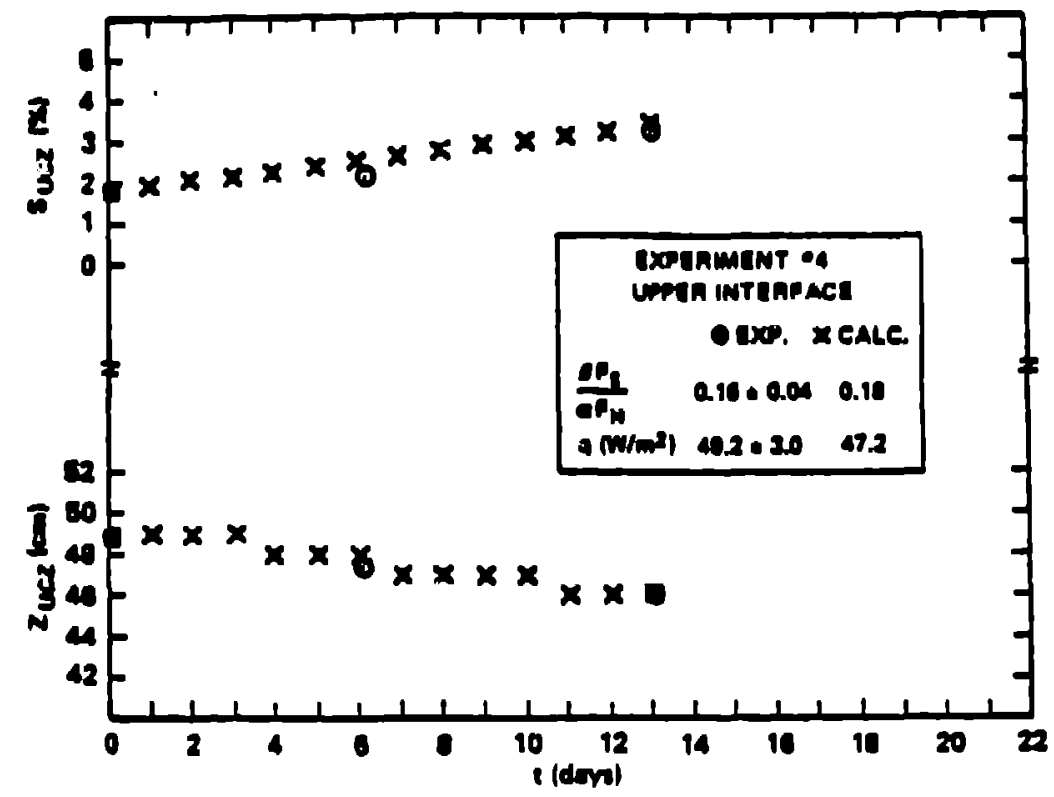

F19. 17. Conparison of observed and calculated results for laboratory tank expertment number 4. $Z$. height of boundary layer above pond bottorn. $F_{H}=F_{h} / o c_{p}$.

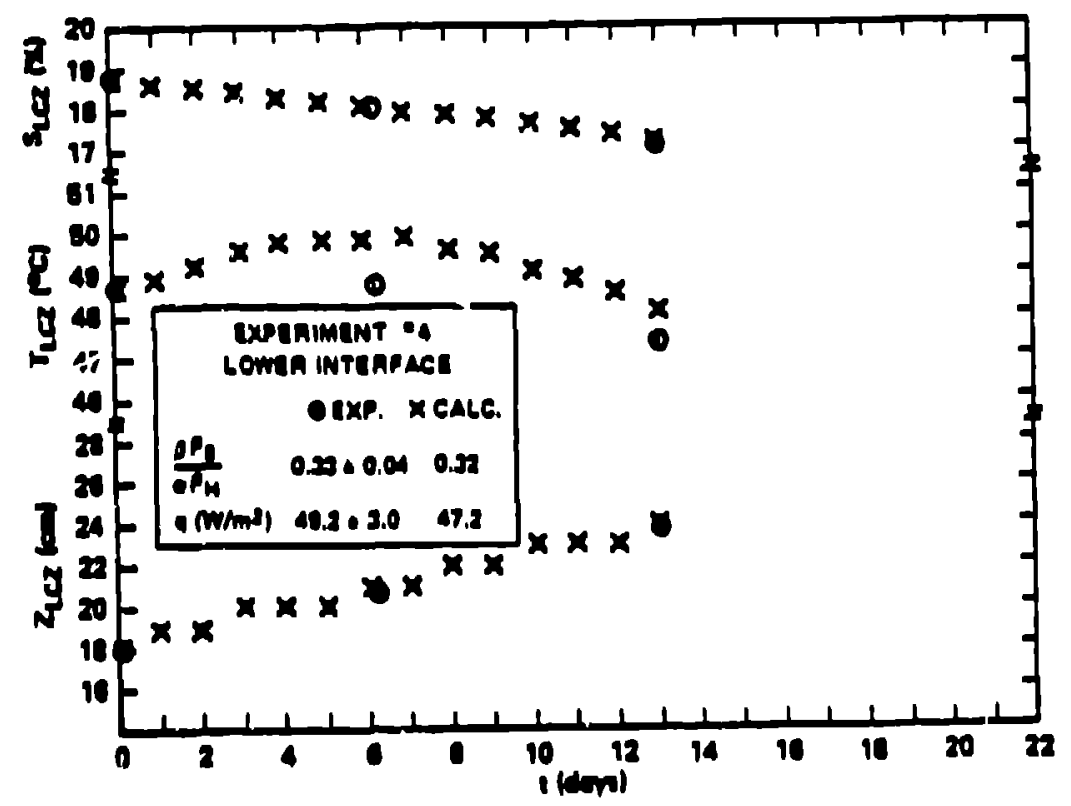

F1g. 18. Comparison of obsorved and calculated rasults for iaboratory tank expertment number 4 . $Z$. helght of boundary layer above pond bottom. FH. Fh/pep. 


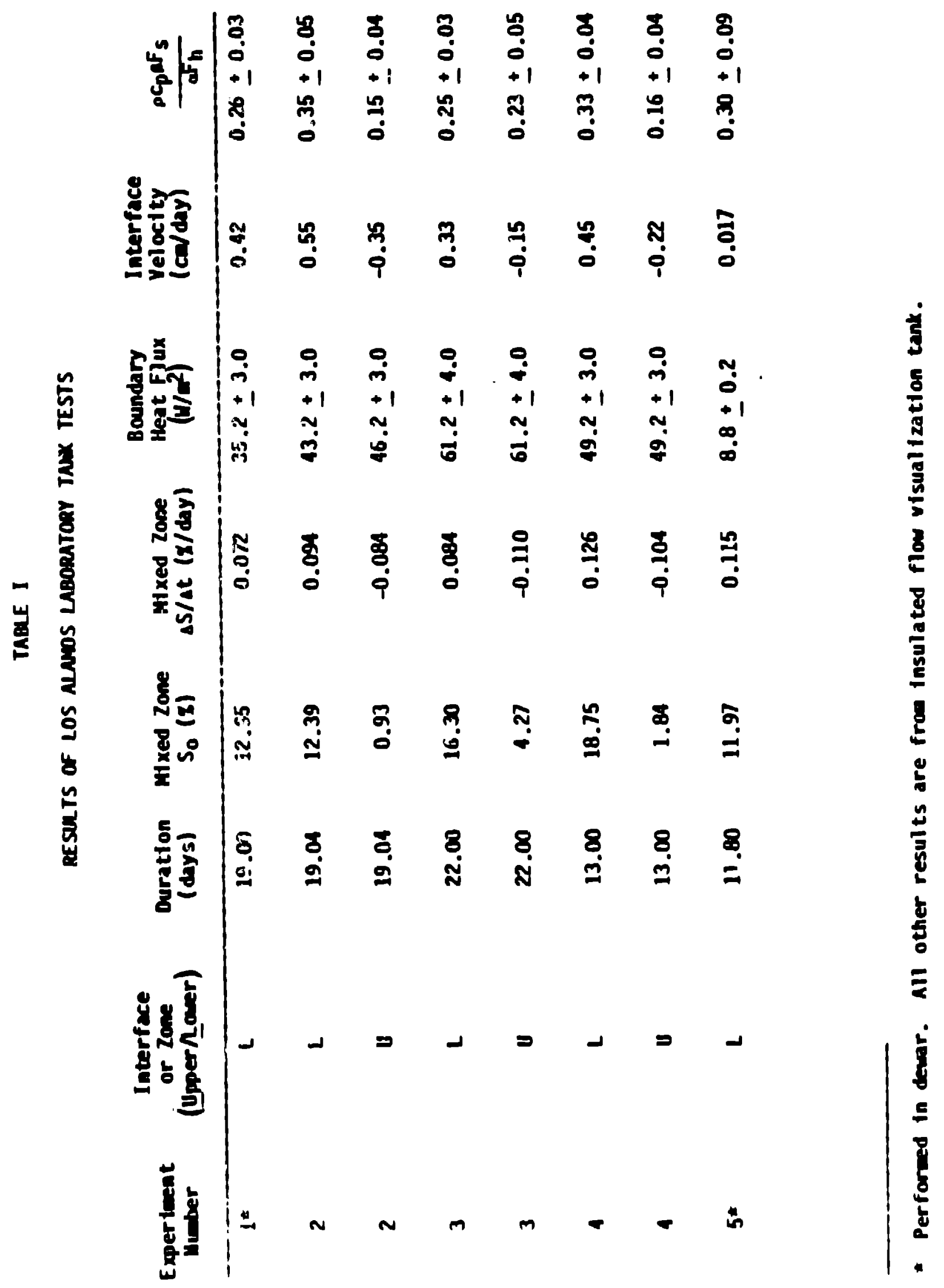


The pond had to be cooled in preparation for the experiment; as of May 1, 1983, the LCZ temperature had risen to $55^{\circ} \mathrm{C}$. The re-installation of the catwalk and instrumentation (after the leak projlems), instrument calforation, and other preparations delayed the start of the experiment.

The pond was cooled by two 11 quid/air heat exchangers, each with a rated capacty of about $30 \mathrm{~kW}$. Pond temperature proflles for the beginning, middle and and of May, 1983 and the beginning of June are shown in Fig. 19. The suction port for the cooling lcop, located near the pond bottom, consisted of a round plece of PYC pipe, $7.6 \mathrm{~cm}$ in diameter. The discharge to the LCZ was through a diffuser conststing of two circular acrylic plates, $1 \mathrm{~m}$ in diameter with a gap between then $7-\mathrm{mm}$ deep.

For the first half of May, the diffuser position was about $40 \mathrm{~cm}$ above the pond floor; the temperature of the pond for May 15 is shown in Fig. 19. After May 15, we moved the diffuser upward to about $70 \mathrm{~cm}$ to involve more of the LCZ in the cooling; note in Fig. 19 that the temperature profile on May 31 reflects this change. The rate of hect extraction from the pond varied from 18 to $38 \mathrm{~kW}$ during this perfod. The mean veloctty from the diffuser was about $0.2 \mathrm{~m} / \mathrm{s}$. The temperature difference between the inlet port and outlet diffuser in the LCZ varied from 5 to $11^{\circ} \mathrm{C}$. No measurable boundary erosion occurred al though the overall Richardson number (R1。 deftned by Eq. (9)), based on diffuser velocity and distance from diffuser to interface, ranged from 0.2 to 0.95 .

TEMPERATURE VS DEPTH

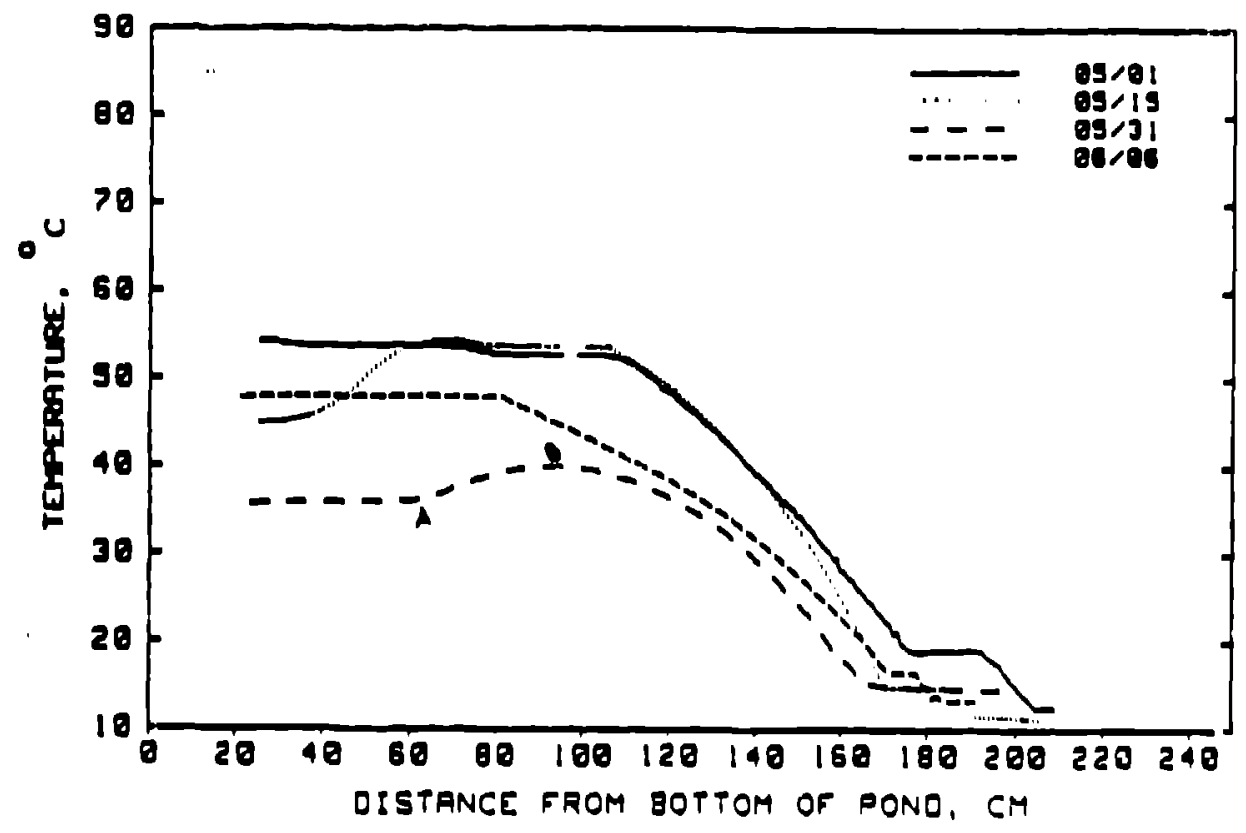

F19. 19. Temperature Proflles of Solar Pond For Four Days Before Beginning Run-Down Experiment. 
Fron FIg. 19, we al so noto that betwen points $A$ and $B$ the pond is stabilized by teaperature, this being a ragion of uniform salinity. Fron point $B$ to the UCZ boundary, the pond is salinity stabilized. Because diffuston is the oniy mechanism for salt transport between point $A$ ind the UCZ boundary, an increase in the thickness of the diffusive core (gradiellt zone) results, as shown by a comparison of the teiperature proflles for May 1 and June 6.

Unfortunately, the heat exchangers were unable to compete with the combination of dafly heat gain in the pond and the stored heat. They were capable of reducing the temperature only to about $36.5^{\circ} \mathrm{C}$ at the bottom of the pond.

On June 1, as detacted in Fig. 19, the top $30 \mathrm{~cm}$ of the UCZ was removed and replaced with fresh weter to prepare for the run-down experfwent. The temparature profiles in the UCZ show this activity. It appears that some erosion of the core occurred during this operation.

Salt water samples were extracted on four days during the run-down for in situ calfbration of the conductivity probe. Temperature and salinity profiles in the pond for the days on which the samples were extracted are shown in Figs. 20 and 21 , respectively. Salinity was measured by the point-conductivity probe callbrated on the days shown in the figures; temperature was measured with an RTD. On the first

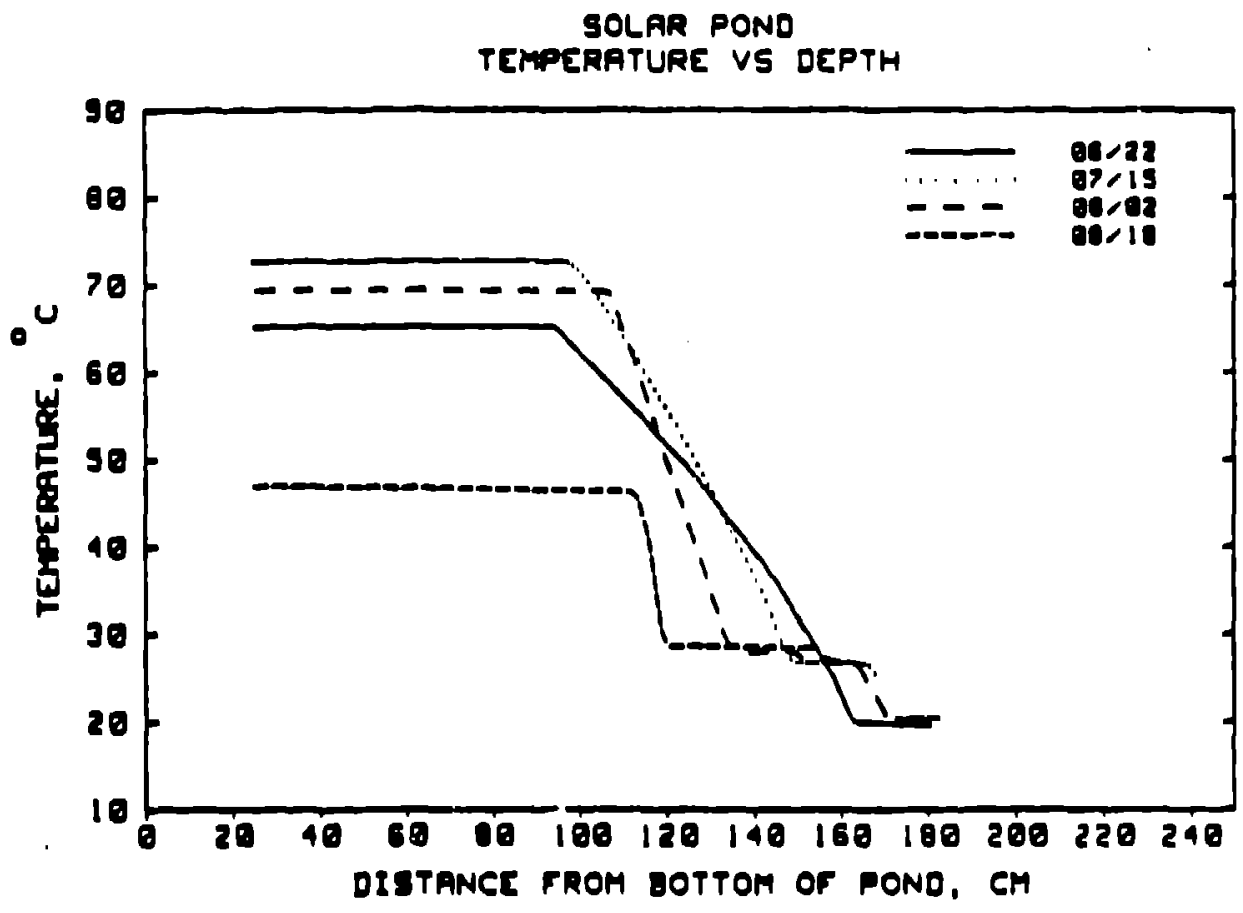

F1g. 20. Temperature Proflies in Pond During Run-down Experiment. 
day of extraction, the inftial temperature and salinity of the LCZ were $65.1^{\circ} \mathrm{C}$ and 18.15 respectively. The S-shaped salinity proflles indicate an Imbalance between the salt transport rate through the interfaces and the rate of salt diffuston through the core. This behavior persisted until near the end of the experiment, at whtch time very large rates of salt transport through the core existed.

Fluctuations noted in the salinity profiles in the LCZ (Fig. 21) are not belfeved to be real, but to be caused by a deterforating platinum coating on the polnt-conductivity probe tip. Fortunately, the salinity values for the LCz used in the salt flux calculations are from extracted samples and not from probe readings.

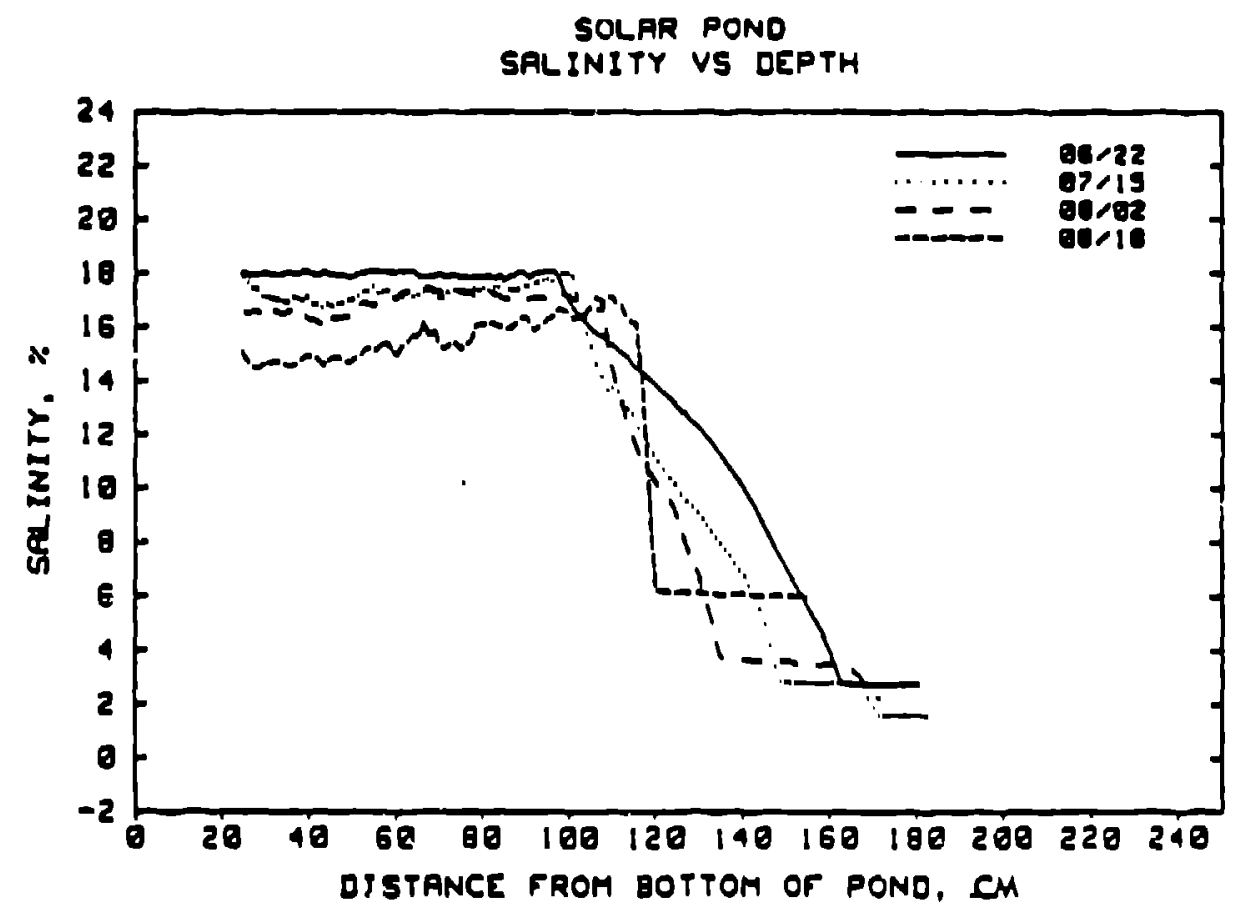

F1g. 21. Salintty Profiles In Pond Durting Run-Down Experiment.

Flux rattos and other pertinent results from the run-down experiment are presented in Table II. The heat flux at a boundary layer botween a mixed zone and the diffustve core was corrected for volumetric heating. This correction was small, however, because the temperature and salintty data were obtalned during hours close to sunset. 


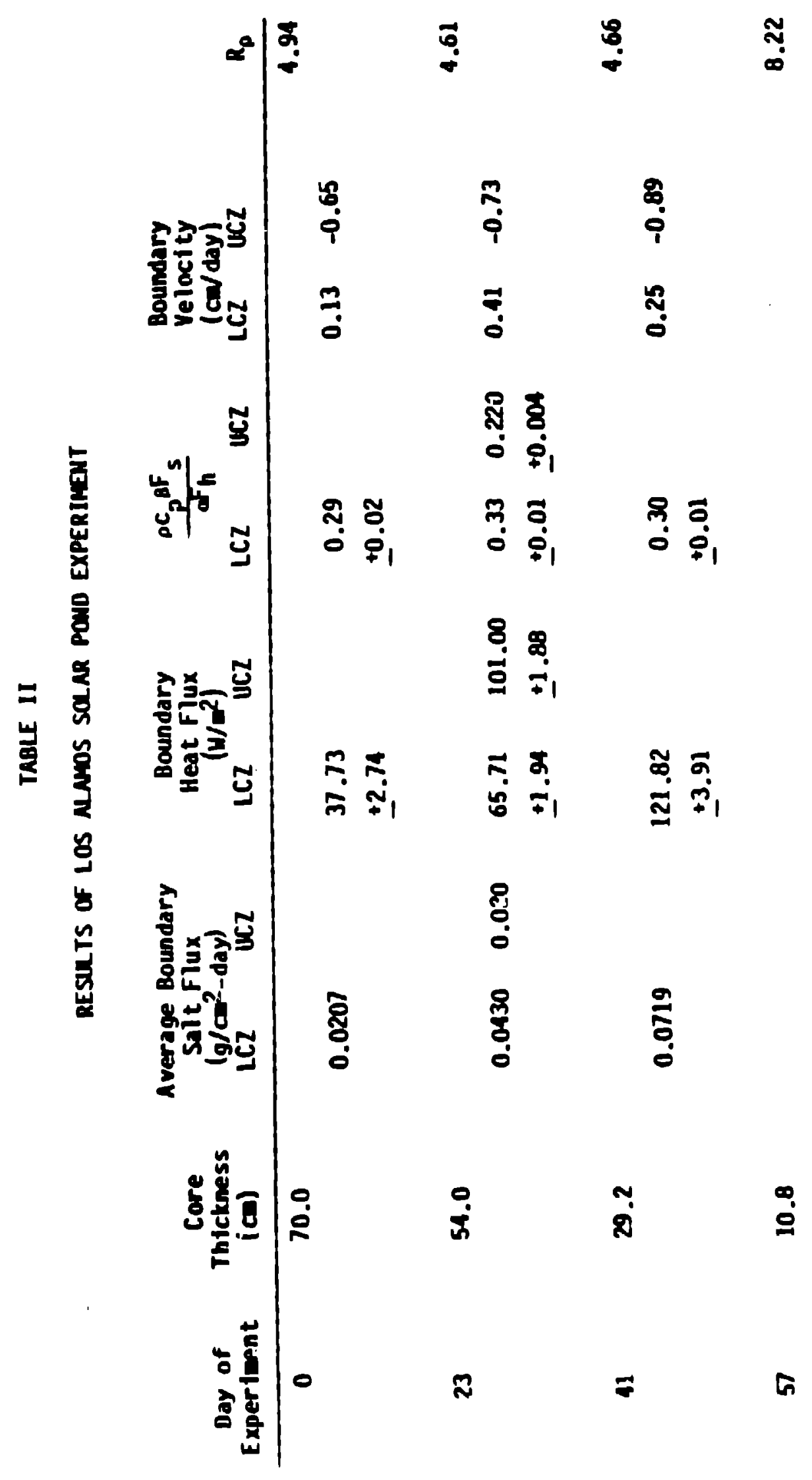


From the results presented in Table II, we first note that the rate of run-down was rapid: on the average about $1 \mathrm{~cm} /$ day was lost from the core. This is more obvious by inspecting fig. 22 where the interface locations are shown over the duration of the experiment. He arriyad at one possible explanation for the rapid run-down by constdering the relatively small values of the overall density-stability ratios shown in Table 11. Newell (Ref. 14) Indicates that the operational 1 imit of solar ponds corresponds to an $R_{p}$ value of about 7 to 8 . Because $R_{p}=5$ for wost of the experiment, based on this criterion, the salintty gradient was not large enough to support the temperature gradtent and a rapid run-down transpired.

A graph of the temperature in the LCZ during run-down is shown in Fig. 23 . In the begiming of June, the rate of warmup was about $1.1^{\circ} \mathrm{C} /$ day with a core thickness of about $70 \mathrm{~cm}$. He note the rate of temperature decrease to be about three t1mes this value for the end of the experiment when the core thickness was only about $20 \mathrm{~cm}$.

The average sait flux from the LCZ over the flrst 23 days of the experfment was about $76 \mathrm{~kg} / \mathrm{m}^{2}$-year, and for the second 18 days 1 was about twice that amount. The smaller number is about 3-1/2 times the maximum measured value for this phenomenon clted by Nielsen and Rabl (Ref. 43). This result is partiy

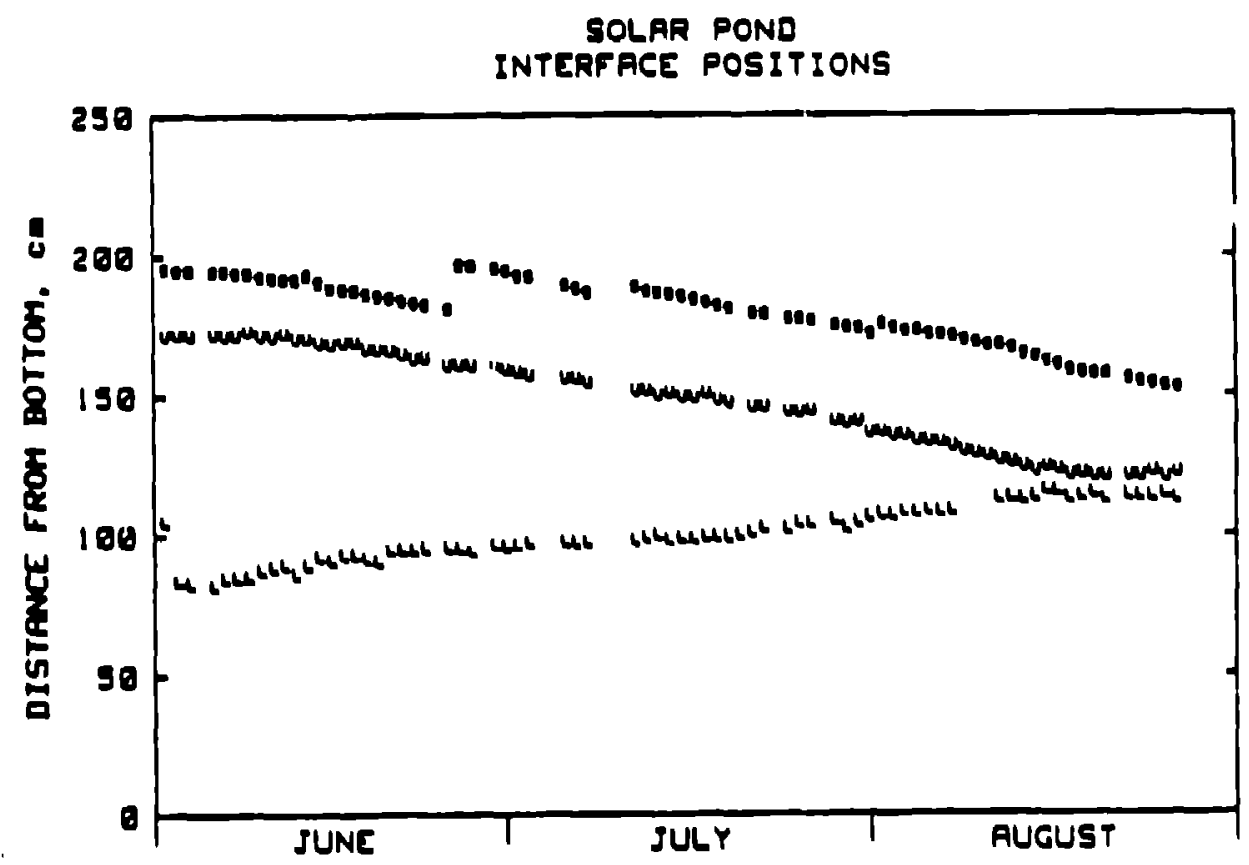

F1g. 22. Locations of the LCZ (1), UCZ (U) Interfaces and the surface location (s) in the pond during a run- Hown experiment. 
explatned by our measured flux rattos that are larger than Niel sen's (Ref. 42) (see discussion belowl. Also, the hat fluxes through the laterfaces over the course of the run-down experiment were larger than for a pond operated in a quast-steady mode. The larger heat fluxes then give rise to larger salt fluxes as indicated by Eq. (12).

The conststently larger values of the UCZ interface velocity compared with that at the LCZ, as soen in Table It, may indicato that a leak stllI oxists in the liner at the bottom of the pond. A comparison of evaporation rates mesured for the evaporation pond with those in the main pond showed a discropency of about $0.4 \mathrm{ca} /$ day over the duration of the experiment. Because of the difference in pond size and botton reflectivity wo suspect this value to be high and the leak rate to be about $0.2 \mathrm{~cm} /$ day. Fortunately, because the total leakage over any inventory perfod is only a small fraction of the volum of the $L C Z(<59)$ the effect of a possible leak on the salt flux and flux ratto at the LCZ interface is small. The offect of a possible leak has been accounted for in the error range for the flux ratios shown In Table II.

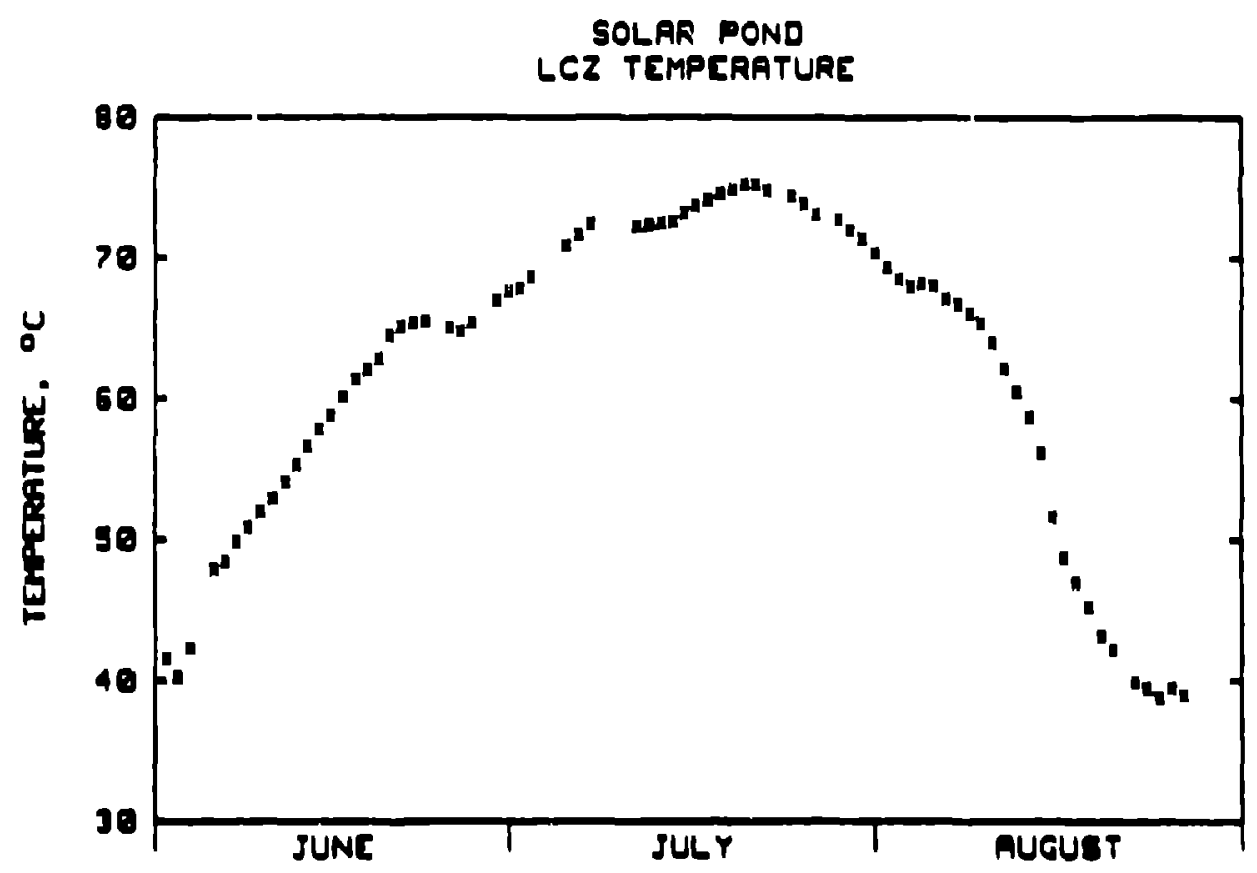

F19. 23. Temperature of LCZ during the solar pond run-down. 
Figure 24 shows the dimensionless salt-to-heat flux ratio with error range as - Punction of heat flux for our laboratory and pond experiments. He have also Included in the flgure results from Broughton (Ref. S4) and Mararino and Caldwall (Rof. 6). We have expressed Mtelsen's (Ref. 42) correlation in a form compatable with the Marmartino and Caldwill results and plotted it as a solld curve. In addttion, the correlation used by Moyer [Rof. 16 and Eq. (16)] to match the predictions from his numertcal modal to the Purdue data is shown as a dotted curve. For the Los Alamos data, the partfally shaded boxes rofor to the results obtained for the LCZ Interface and the unshaded boxes refor to the UCZ-Interface results. Fron inspection of Flg. 24, w belleve the relattvely good agraement supports our conjecture that the sawe phystcal phenomena are present in both therwohal ine columns and solar ponds. Although the data 13 scattored, the trand toward a smaller flux ratio at larger heat fluxes is perceptible. In addition, we note that the Nielsen correlation to solar pond data bounds our results from below. We further note the Meyer corralation to be in much better agreement with the data than the Nielsen corralation in the moderate-to-large hat flux range. The relatively good agraement between the flux ratios for the laboratory tank experiments and those from the pond indicates that the effects of convective mixting from bottom heating on salt transport through the LCZ boundary may not be as stgniffeant as originally shought. More flux-ratto date for large ponds are needed to answer this question.

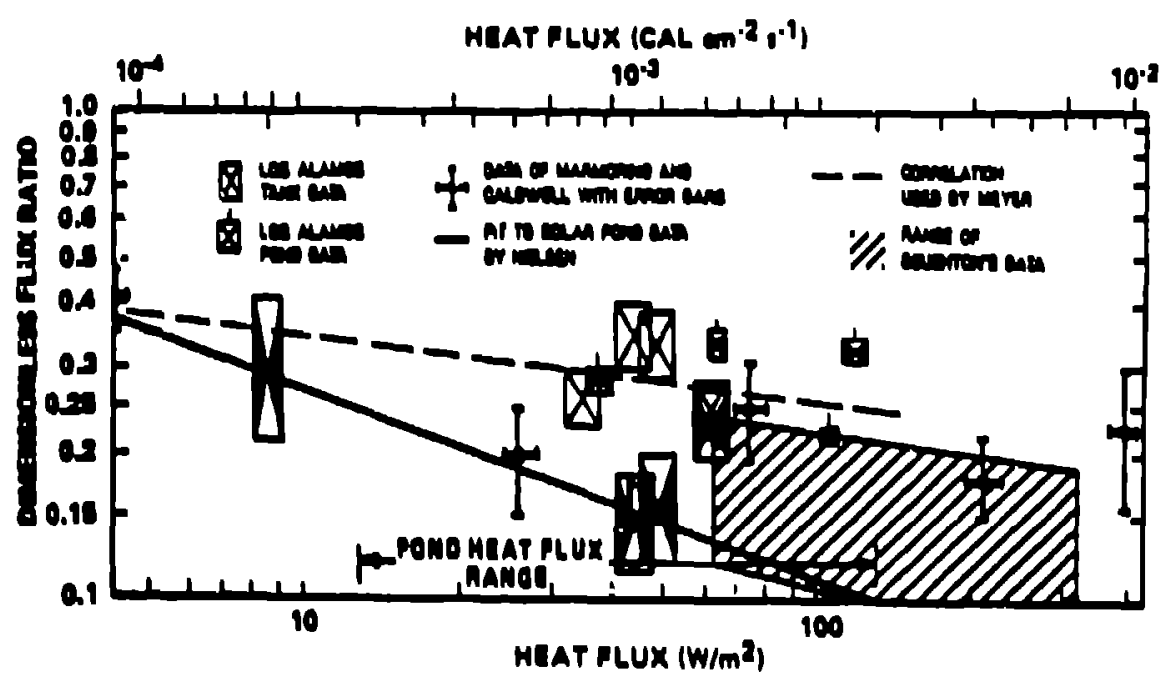

F10. 24. Oimenstonless salt-to-heat flux varsus heat flux for pond experiment and laboratory tank tests. 


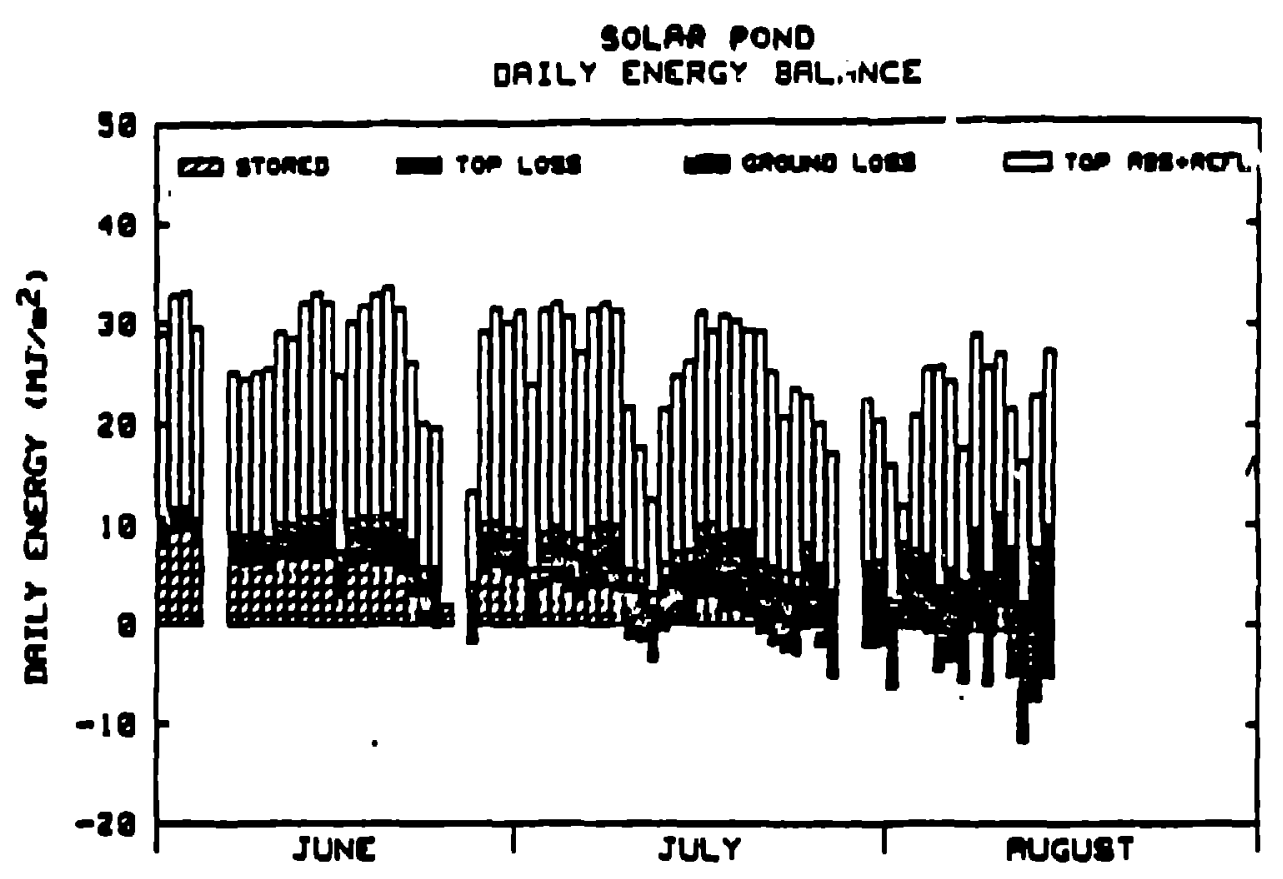

F1g. 25. Energy flows in solar pond. Pertod of experiment, June 22 through August 18.

It is interesting to compere the results from the run-down experiment with the Criterfa for stable Interfaces proposed by N1elson and Rabl (Ref. 40) and Newell and Boohm (Rof. 43). From our data wo obtain a t1me-averaged ratto of the difforence in salinity to the difference in temperature between the nixad zones of $0.343 \% /^{\circ} \mathrm{C}$. Based on this result, Eq. (5) predicts that the interfaces in the pond are stable whereas a rapld run-down ectually occurred. The expression 0.22 G $g_{\text {aG }}$. averaged in time, is about 90 based on our data. Eq. (8) predicts a shrinking of the inf xed layers for this value al though the actual behevior was quite different.

From these results, It appears the ragime of conditions existing in our pond during run-down was quite different from the ones on which the stabllity criterte mre based. More theoretical and experimental work must be done bofore wa are able to develop accurate stabllity erfterla for Interfaces in solar ponds.

A ber graph of dally onergy flows in the solar pond is shown in fig. 25 through the and of the run-down experiment. From these rasults, the average pond afflctency over this perfod is slightly grester than 20x. Virtually no energy storage occurred in the pond after the middle of July because of the rapid thinning of the core after that time. A tabulation of the dally onergy flows 18 presented in Table IIt. Symbols are dopined in Table iY. 
ㄴ. I 1 में

군 구ำ

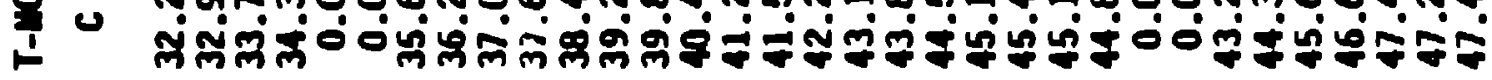

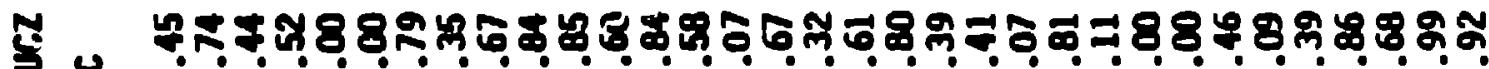

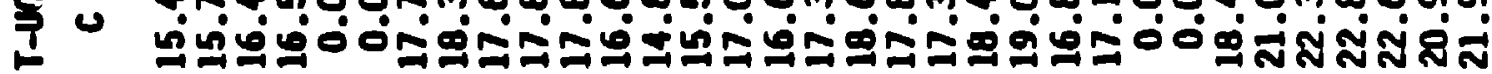

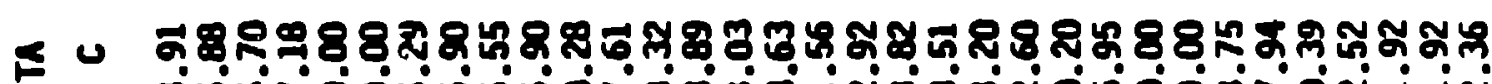

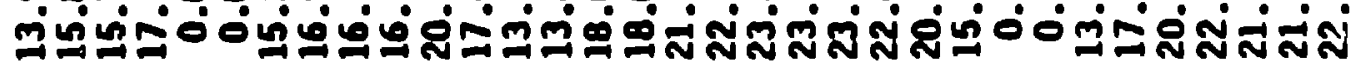

ᄂ

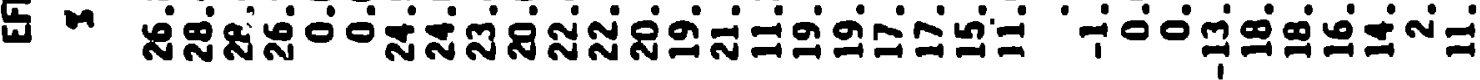

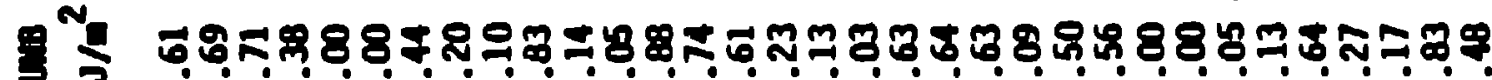

党

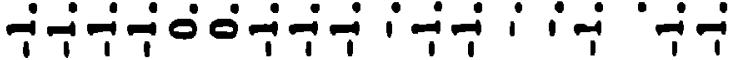

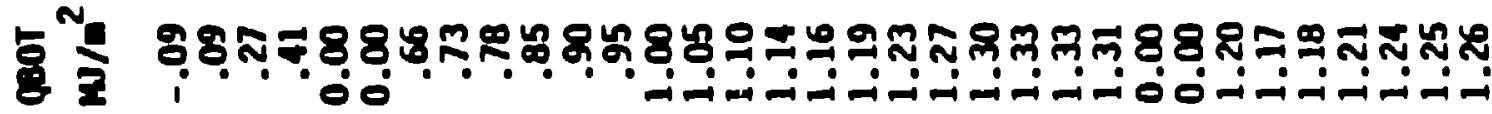

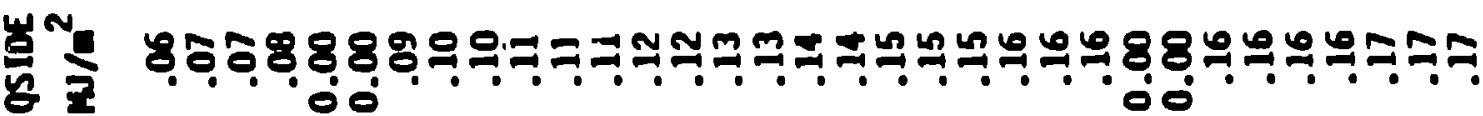

8

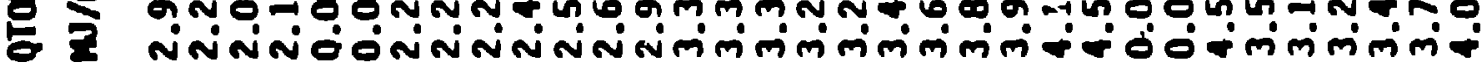

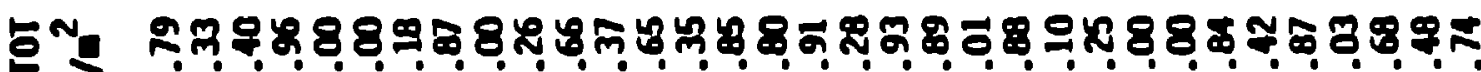

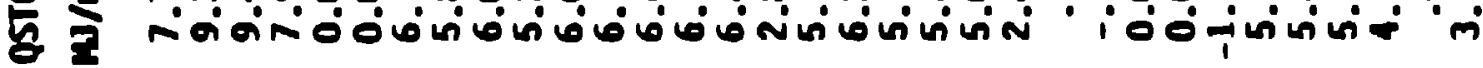

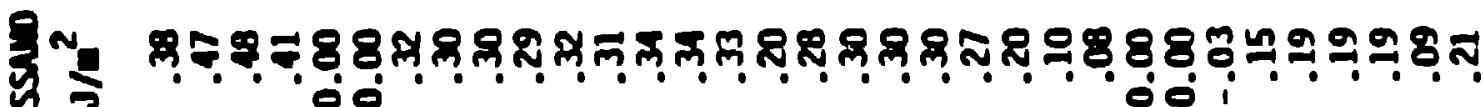
82

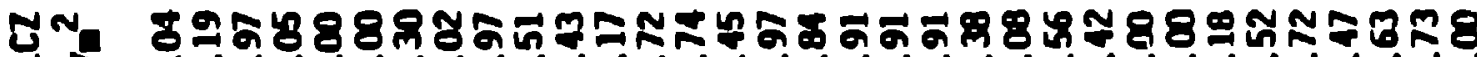

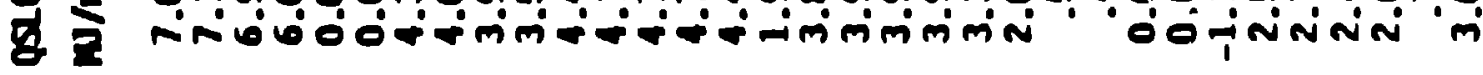

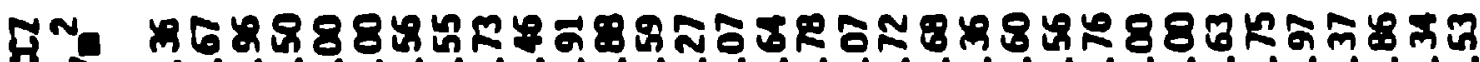

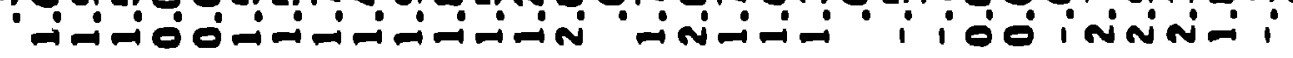

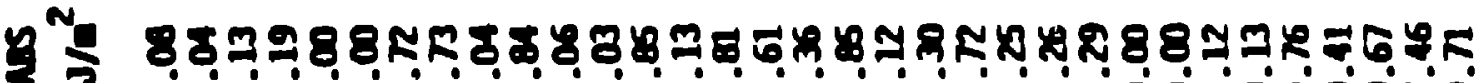

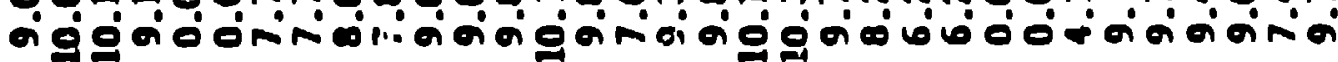

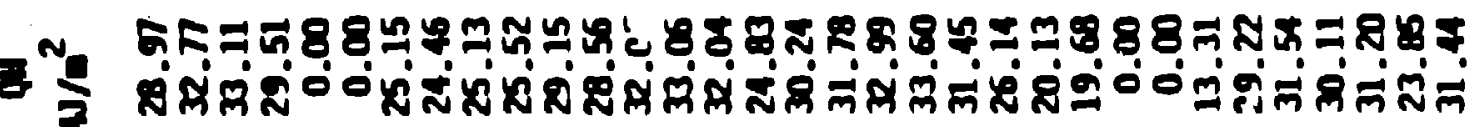

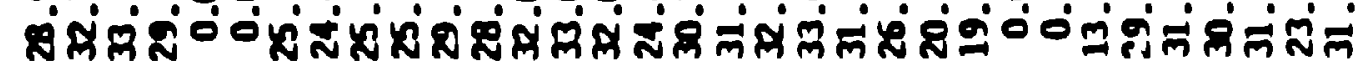

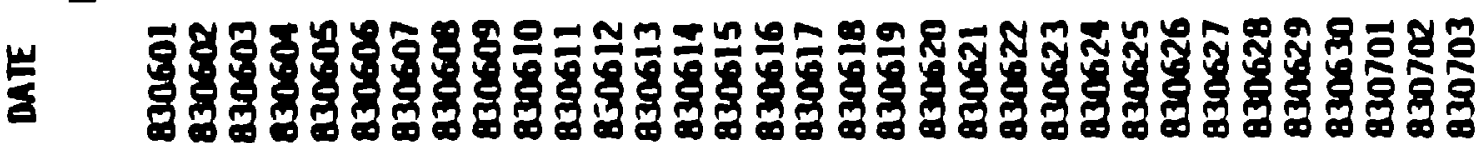

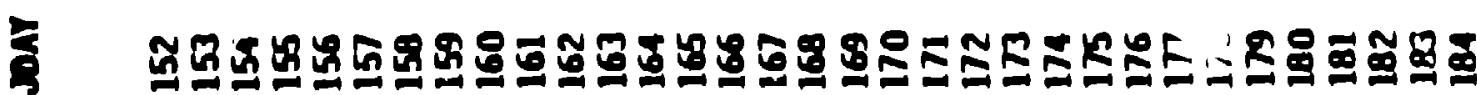


y

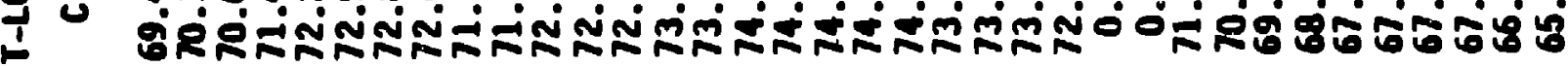

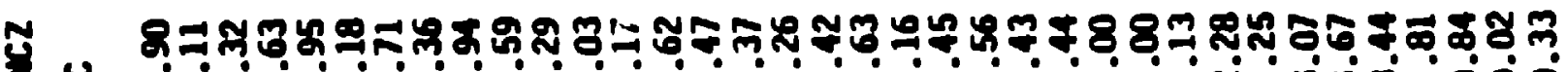

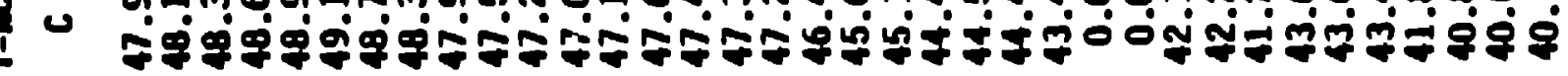

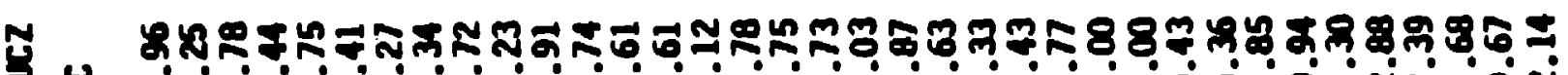

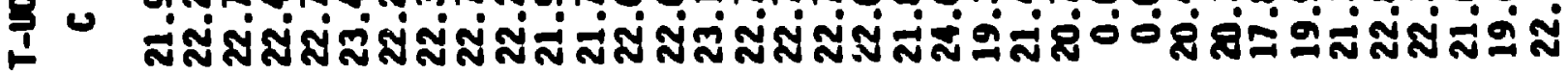

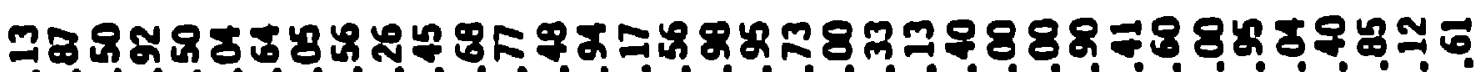

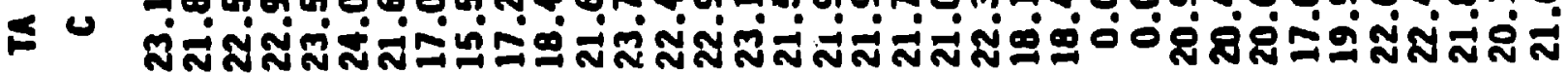

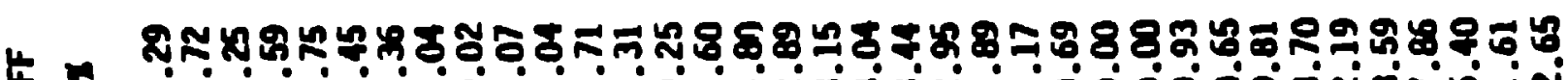

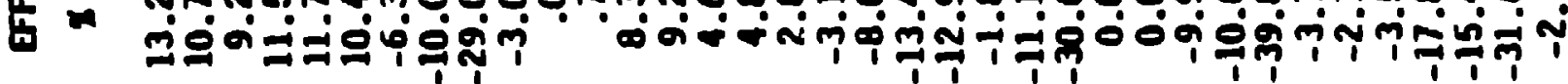

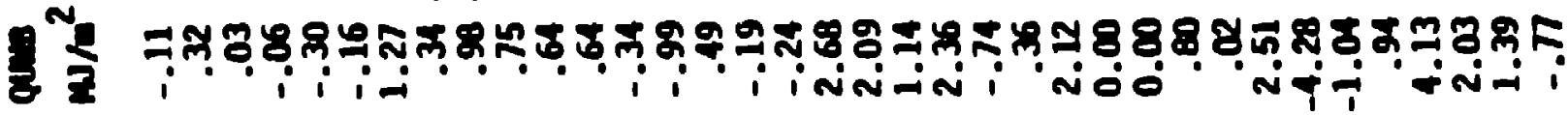

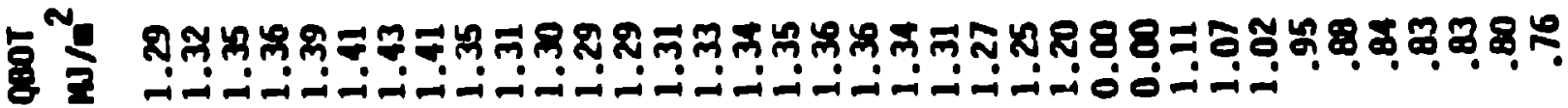

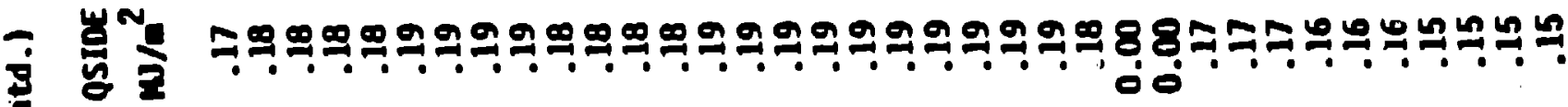

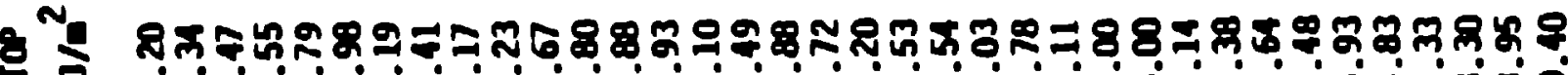

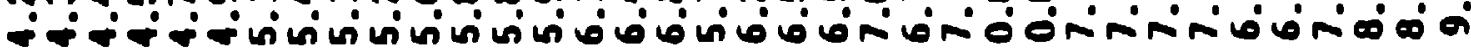

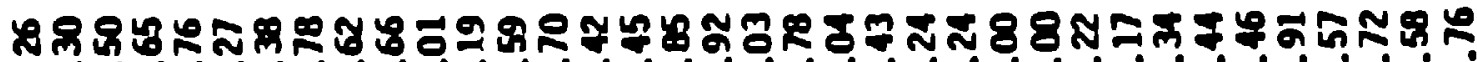

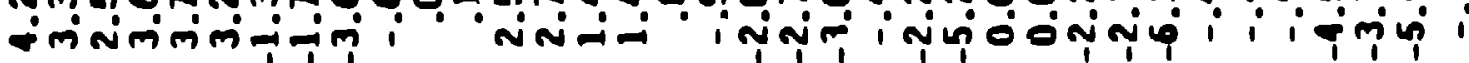

동

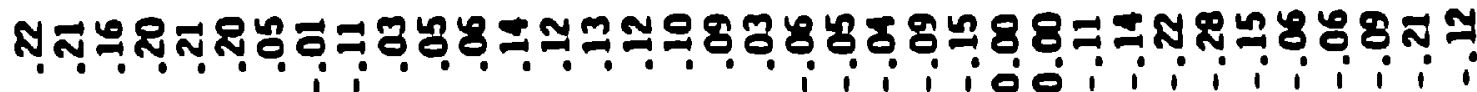

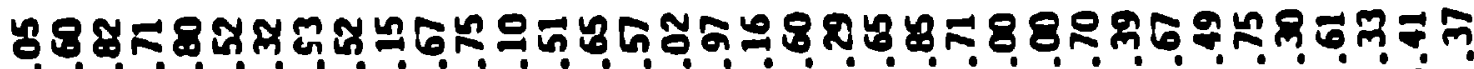

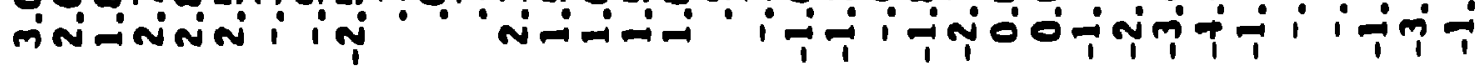

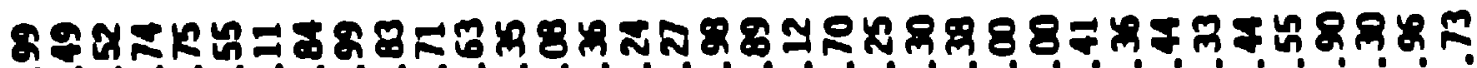

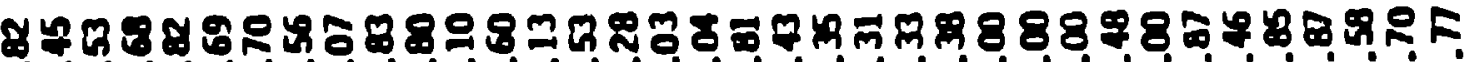

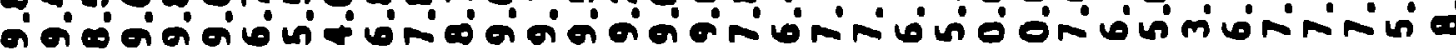

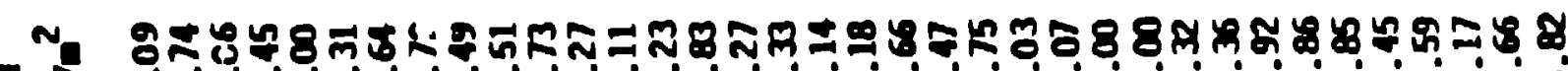

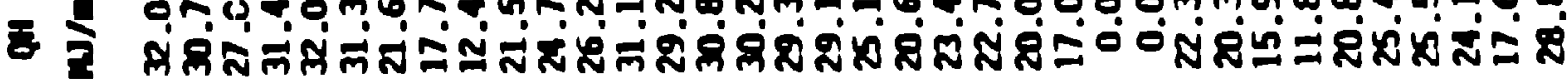

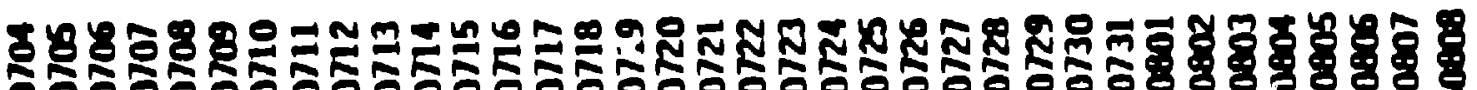

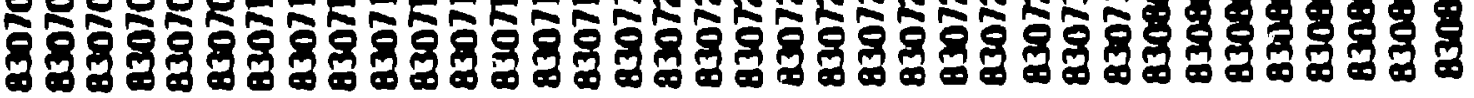

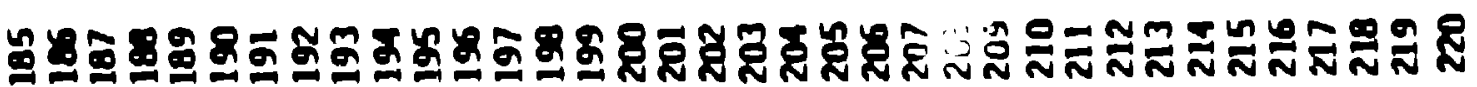




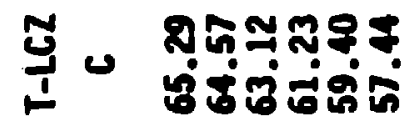

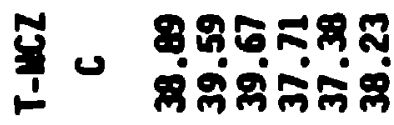

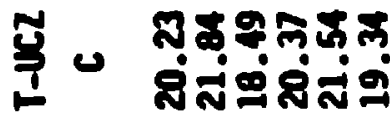

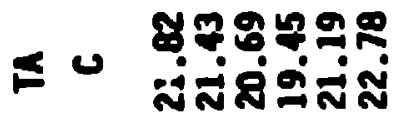

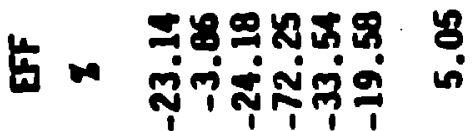

娄

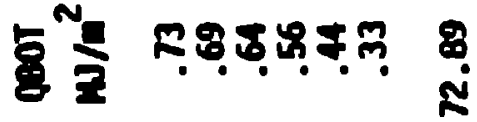

胥

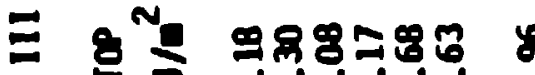

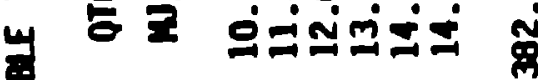

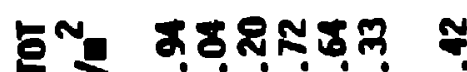

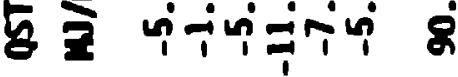

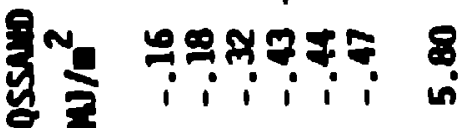

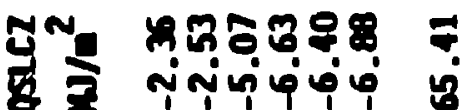

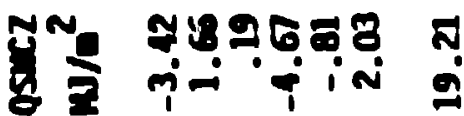

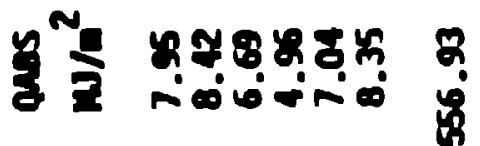

₹

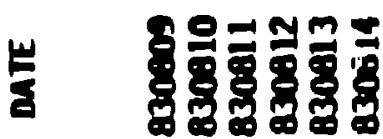

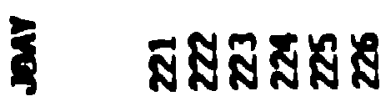




\section{TABLE IV}

DESCRIPTIOH OF TERMS IN TABLE III

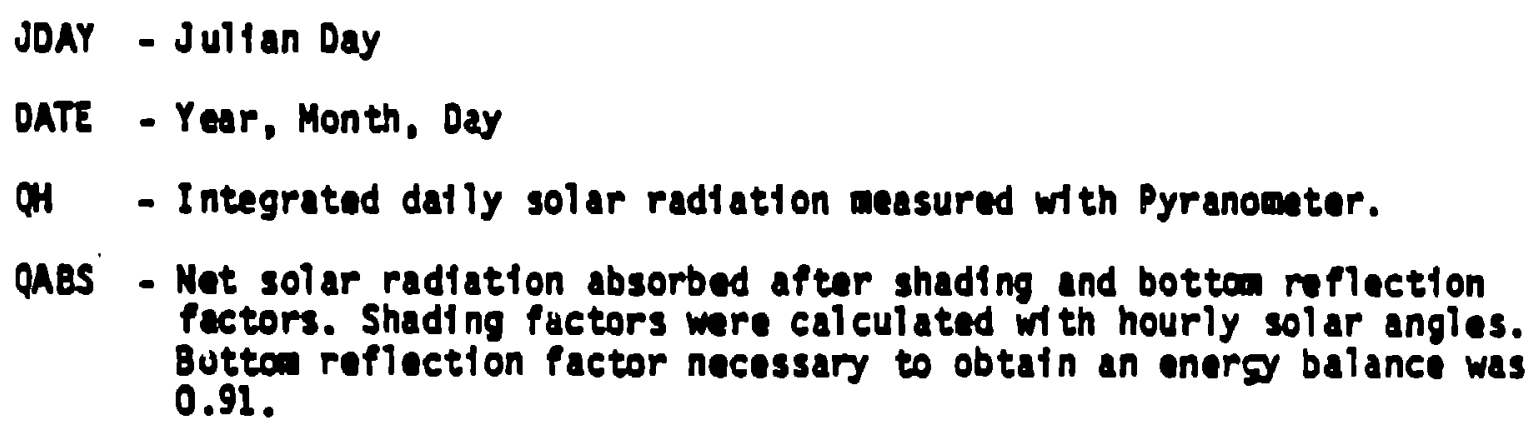
factors. Shading factors were calculated with hourly sol ar angles. Button reflection factor necessary to obtain an energy balance was 0.91 .

QSNCZ - Emergy stored in hion-convecting zone. Calculated with (density $x$ speclffe heat $\left.-3.975 \mathrm{~mJ} / \mathrm{m}^{3}\right) \times 20 n e$ depth $x$ zone temperature dafly change.

QSLCZ - Enargy stored in lower-convecting zone. (Density $x$ spacific heat $3.891 \mathrm{MJ} / \mathrm{m}^{3}$ ) and above equatt on. Zone dapth . $110 \mathrm{~cm}$.

QSSAND. Energy stored in botton sand layer. (denst ty $x$ spectflc heat $=1.21$ $\mathrm{MJ} / \mathrm{m}^{3}$ ). Sand depth $=25.4 \mathrm{~cm}$.

QSTOT - Total onergy storage. Sum of above 3 terms.

QTOP - Heat loss back to amblent through top surface of pond. Calculated with actual UCZ thickness with dafly average temperature difference and $K=0.6 \mathrm{H} / \mathrm{m} \mathrm{K}$.

QSIDE - Heat loss through sides of pond. Calculated w'th average temperature difference of 4 sots of side measurements at 0 and $46 \mathrm{~cm}$ depth into carth. $K$ assumed to be $0.5 \mathrm{~W} / \mathrm{m} K$.

QBOT - Hent loss at bottom of pond. Calculated with average temperature difference of 2 sots of measurements at 0 and $46 \mathrm{~cm}$ depths. $K$ assumed to be $0.85 \mathrm{~W} / \mathrm{m} \mathrm{K}$.

QUMB - Dally onergy unbalance. QABS-QSTOT-QTOP-QSIDE-QBOT.

EF - Rat1o of stored energy (QSTOT) and total horuzontal solar energy (QH).

TA - Average datly amblent temperature.

T-UCZ - Average dally upper convecting zone temperatura.

T-NCZ - Average daliy non-convecting zone temperature.

T-LCZ - Average dally lower-convecting zone temperature. 
A cne-dimanstonal wodel has been developed that is capable of accurately predfeting tim-dependent, mixed-zone temperature, salinity, and interface motion.

The correlating parameter in the model is the dimensionless salt-flux-to-heatflux ratto (flux ratlo) as a function of interfactal heat plux. In our experiments, whave obtatned 12 values of the flux ratfo for heat fluxes ranging from 8 to $100 \mathrm{~N} / \mathrm{m}^{2}$. Howver, only 4 of the 12 polnts were obtalned from a large pond. More dymanic performance data for large ponds are needed to (1) compare with new theoretical results, (2) complete model validation, and (3) answer the Important question of salt replentshment. More data on heat extraction and rejection in actual solar ponds are required to validate the results obtalned in laboratory experiments.

The 1ssue of ground loss and lts effect on pond performance requires additional attention. A study should be done to dotermine the effect of ground loss on the overall Impact of ponds by considering that future pond sites are restricted to those areas where subsurface conditions pormit them to operate efflciently.

Problems continue to exist with pond liners (Rof. 65), methods to determine leak location and in situ repair without disturbing the pond. Divers are not the answer. Research on the physteal processes occurring at the boundartes of a linerless pond should be intelated.

The ares of Instrumentation requires attention. In particular, there is a need for raliable instrumentation to accurately measure fluld speciftc gravity in st tu wth spattal resolution of $0.1 \mathrm{~mm}$ and smaller. Accuracy should be $10^{-4}$ or bettar. We feel that such an instrument could be developed (Ref. 55). Its measurements would provide data to answer many quastions on the fluid dynamics in the fimmadiate nelghborhood of a mixed zone/core intarface, juch as the intermittant entral mient of a dynante boundary layer.

Some coururefally avaliable Instruments should be lmproved. The Beckman Induction salinomer installed at the pond falled just before beginning our run-down expertment. Salt water intrusion in the cell was blamed but not proved. Performance of the Eppley 8-48 underwater pyranometer at the pond is suspect because of condensation (or salt water) on the instde of the globe and salt-water attack on the outside of the globe that caused scratches. 
Both tanks and associated hardware are st111 intast and may be used again wf thout much preparation. The data-acquisition system for the dewar experiment is on permanent losin to another group in the laboratory. It will be difficult to retriave it.

The pond needs work. If there is a leak in the liner, we suggest that a new liner be installet on top of the old one, which could first be patched and used as a back-up. More seit is needed. Both the undermatar pyranometer and the Beckman salinometer need repair. Other Instrumentation at the pond remains intact. The data-aequistition system was removed from the pond site but is stfll avallable if noeded. The traversing mechantsin should be modfffed to eliminate a sticking probiem.

\section{ACKNOWLEGMENTS}

This roport is the work of many people: D. A. Neeper provided insight and suggestions; K. Hedstrom, C. Bates, and J. Orefcer worked with the experiments; L. Dalton, J. Tafoya, B. Ketchum, L. Brewer, and J. Hauser contributed to the constructi on of the pond ano the experiments.

Tht.s study was funded in part by the U.S. Department of Energy, Division of Solar Thermal Energy System and Active Heating and Cooling Diviston; Office of Solar Heat Technolegtes; and Offtce of Solar Applications for Butidings. It was also funded in part by an Internal supporting research grant from the Los Alamos National Laboratory. 


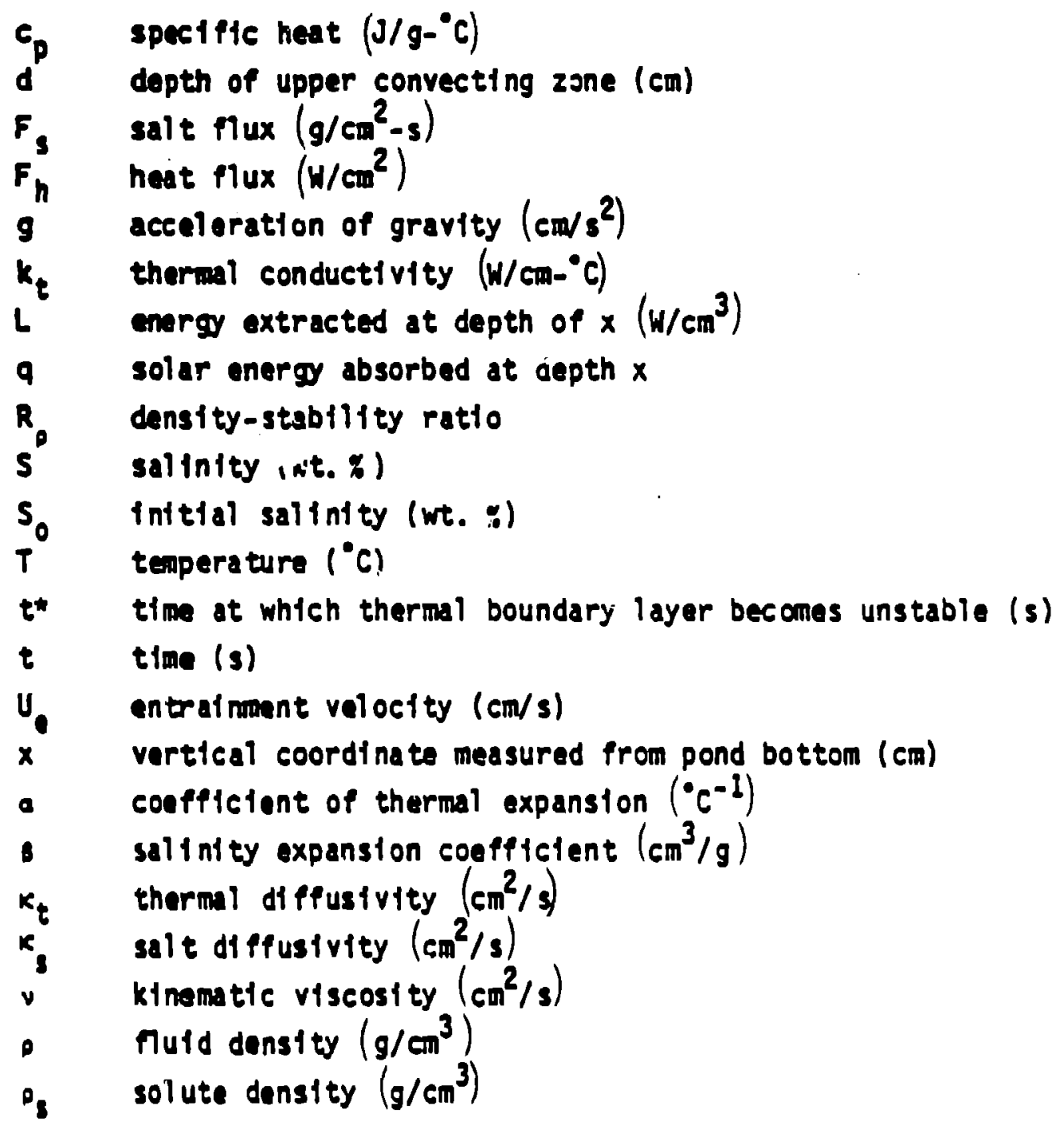


1. R. Viskanta and J. S. Toor, "Absorption of Solar Radtation in Ponds," Journal of Solar Energy, 22, 59 (1978).

2. A. Rabl and C. E. Ntelsen, "Sol ar Ponds for Space Heating," Journal of Solar Energy, 17. I (1975).

3. M. N. A. Hawlader, "The influence of the Extinction Coeffictent," Journal of Solar Energy, 25, 461 (1980).

4. H. E. Huppert and J. S. Turner, "Double Diffusive Convection," Journal of Fluid. Mechantcs, 106, 299 (1981).

5. P. F. Crapper, "Measurements Across a Diffusive Interface," Deep Sea Research, 22, 537 (1975).

6. G. O. Marmarino and D. R. Caldwil, "Heat and Salt Transport Thrügh A Diffusive Interface," Deep Sea Research, 23, 59 (1976).

7. W. R. LIndberg and R. D. Haberstroh. "A Thermohal ine Convection Model "Office of Naval Researeh Project NR-083-250, Tech. Report No. 1 (November 1971).

8. P. F. Linden and T. G. L. Shirtcliffe, "The Diffustve Interface in Double Diffusive Convection," Journal of Fluid Mechantes, 87, 417 (1978).

9. E. M. Sparrow, R. B. Husar, and R. J. Goldstetn, "Observation and Other Charactartstics of Thermals," Journal of Fluld Mechantcs, 41, 793 (1970).

10. L. N. Howard, "Convection at High Raleigh Number," Proc. Il th International Congress of Applied Mechantcs, Munich, 1964 (Springer-Vorlag, Berlin, 1964).

11. J. S. Turner," The Coupled Turbulent Transports of Salt and Heat Across A Shirp Density Interface," Int. Jour. of Heat and Mass Transfor, 8, 759 (1965).

12. J. S. Turner," The Behavior of a Stable Salintty Gradtent Heated Frora Below," Journal of Fiutd Mochantes, 33, 183 (1968).

13. T. A. Newall and P. M. Yon Drtska, "Double Diffustve Convecti on Across a Single Interface at HIgh Density Stab1lity Ratio." Natural Convoction in Enclosures - 1983, ASke HTD-Vol. 26, 1983 (Amertean 5ocTety of Mechantcal Engthers, New rork, 1983).

14. T. A. Newel1, "Characteristics of a Double Diffusive Interface at High Density Stablitty Ratios," subaltted to Journal of Fluld Machanics.

15. T. R. Mancint, R. I. Loahrke, and R. D. Haberstroh, "Layered Thermehaline Natural Convection," Journal of Heat and Mass Transfor, 19, 839 (1976).

16. K. A. Meyer, "A Numertcal Model to Describe the Layer Behavtor in Salt-Gradtent Solar Ponds," Journal of Solar Energy Engineering, 105, 341 (1983). 
17. H. Hotnberger, "The Phystes of The Solar Pond, "Journal of Solar Enargy, 8, 45 (1964).

18. G. Voronis, "On Finite Amplitude Instabllity in Thermohal ine Convection," Journal of Marlne Research, 23, 1 (1965).

19. G. Veronis, "Effect of a Stabll1zing Gradient of Solute on Thermal Convection," Journal of Flutd Mechantes, 34, 315 (1968).

20. P. G. Bal nes and A. E. 6111, "On Thermohal ine Convecti on with LInnar Gradients," Journal of Flufd Mechantes, 37, 287 (1969).

21. J. S. Turner, "Double Diffusive Phenomena, "Ann. Rev. of Fluid Mechanics, 6, 37 (1974).

22. J. S. Turner, Lecture Presented at the Double-Diffusive Convectl on Conference, Santa Barbara, Calffornta, March 14-18, 1983.

23. R. Almanza and H. C. Bryant," Osctliatory Mottons in the Non-Conyective Layer of a Solar Pond." Journal of Solar Energy Engineerting, 105. 375 (1983).

24. D. P. Grfmer and G. F. Jones, "Prel1 milnary Evidence for Internal Wave Motion at Boundartes of Convecting and Non-convecting Zones in Layered Thermohaline Columns," International Com. Heat Mass Transfer, 11, 283 (1984).

25. C. E. Nielsen, "Design and Inttlal Operatton of a $400 \mathrm{~m}^{2}$ Solar Pond," Proc. International Solar Energy Soctety Meeting, Phoenix. Artzona, 1980 (International Solar Energy Soctety, Newark, Delaware, 1980), p. 381.

26. C. E. Mrelsen, "Salt Transport and Gradient Malntenance in Solar Ponds, Proc. International Sol ary Energy Soctety Meeting, Houston, Texas, 1982 (Internatlonal Solar Energy Soctety, Newark, Delaware, 1982), p. 179.

27. F. Zangrando and J. Green, "On Heat and Mass Exchange in a Partlally Stratfied Fiuid, to be presented at the 22nd National Heat Transfor Conference, N1agara Falls, New York, August 5-8, 1984.

28 T. L. Borgman, F. P. Incropera, and R. Viskanta, "A Multt-Layer Model for Fixing Layer Development in a Double-01ffustve Thermohal ine System Heated from Below," International Journal of Heat and Mass Transfar, 25, 1411 (1982).

29. P. F. Crapper, "Fluxes of Heat and Salt Across a Diffustve Interface in the Presence of Grid-Generated Turbulence," International Journal of Heat and Mass Transfer, 19, 1371 (1976).

30. J. S. Turner, "The Influance of Molecular Olffusivity on Turbulent Entralnment Aeross a Censity Interface, "Journal of Fluld Mechanics, 33, 639 (1969).

31. J. F. Atkinson and D. R. F. Harleman, "A Wind-M1xed Layer Model for Solar Ponds," Journal of Solar Energy, 31, 243 (1983). 
32. Y. S. Cha, W. T. She, and H. W. Schertz, Modeling Surface Convectt ve Layer of Salt-fradient Solar Ponds," Journal of Solar Energy Engtreering, 104, 293 (1982).

33. C. F. Kool, "Salt Gradtent Solar Pond With Reflective Bottom Application to 'Saturated' Pond," Journal of Solar Enorgy, 26, 113 (1981).

34. C. F. Kool, "The Steady State Salt Gradient Solar Pond," Journal of Solar Enorgy. 23, 37 (1979).

35. J. R. Hull, "Calculation of Sol ar Pond Theoratical Effictency With A Diffusively Refiecting Botton," Journal of Solar Energy, 29, 385 (1982).

36. J. R. Hull, "Computer Strulation of Solar Pond Thermal Bahavfor," Journal of Solar Energy, 2533 (1980).

37. S. A. Shah, T. H. Short, and R. P. Flynn, Modaling and Testing a Salt Gradlent Solar Pond in Northeast Ohfo," Journal of Solar Energy, 27, 393 (1981).

38. R. P. Flynn and T. H. Short, "Sol ar Ponds - A Baste Manual," Spectal Circular 106, The Ohfo State University, OAROC, Hooster, Ohfo (February 1983).

39. M. Edesses, J. Henderson, and T. S. Jayadev, "A Single Design Tool for S1zing Solar Ponds," Solar Energy Research Inst1 tute report, SERI RR-351-347 (Decenber, 1979).

40. T. A. Nomill and R. F. Boehm, "Grao'tent Zone Constralnts in a Salt-Stratiffed Solar Pond," Journal Solar Energy Englneering, 104, 280 (1982).

41. C. E. N1elsen, "Equilibrlum Thickness of The Stable Gradtent Zone in Solar Ponds," Proc. International Solar Energy Soclety Meating, Denver, Colorado, August, 1978 (International Solar Energy Soclety. Newark, Delaware 1978), p. 932.

42. C. E. Niel sen, "Control of Gradient Zone Boundar1es," Proc. International Solar Energy Society Meeting, Atlanta, Georgla, May 28, 1979 (International Solar Energy Soctety, Newark, Delaware, 1979), p. 1010.

43. C. E. N1elsen and A. Rabl, "Salt Requirement and Stabll1ty of Soiar Ponds," Proc. Jolnt Confarence International Solar Energy Socloty and Solar Energy Soctety of Canada, Inc.. Winnepeg, Ontarto, August 15-20, 1976 (Intarnational Solar Energy Society. Newark, Delaware, 1976).

44. C. E. N1elsen, "Surface Zone Behavtor in Solar Ponds," Amertcan Soctaty of Mechentral Englneers paper no. 82-WA/SOL-25, (Amertcan Soctety of Machantcal Englneers, New York, 1982).

45. Y. Jelurla. "Heat Rejection and Energy Extraction WIthin Solar Ponds," Solar Energy Research institute report, SERI/PP.-252-1393 (Fobruary 1982).

46. Y. Jelurfa and C. K. Cha, "Heat Rejection to the Surface Layer of a Solar Pond," Amertcan Soctety of Mechanteal Engtneers paper no. 83-HT-77, 1983. 
47. K. A. Meyer and J. C. Hedstron, "Estlmates of Ground Conduetivity for the DOE-USAFA Exporimental Solar Pond," Los Alawos Natfonal Laboratory report LA-UR-82-2904 (1982).

48. C. Loboeuf and D. H. Johnson, "Effects of Soll Condition on Sol ar Pond Performance," Proc. ASkE-SED S1xth Annual Technical Conforence, Las Vegas, Mevada, Aprit 8-12, 1984 (Amertcan Soctoty of Mechantcal Englneers, New York, 1984).

49. D. A. de Vrfes, "Simultaneous Transfor of Heat and Mol sture in Porous Media." Trans. Am. Geophysical Unton, 39, 909 (1958).

50. $\because$ R. Halkar, J. D. Sabey, and D. R. Hampton, "Studles of Heat Transfor and Water Migration in Solls, Report DOE/CS/30139-TI, Colorado State University, Fort Collins, Colorado, (April 1981).

51 M. Rothweyer, "The Soret Effect and Selt-Gradient Solar Ponds," Journal of Solar Energy, 25, 567 (1980).

52 K. A. Meyer, D. P. Grimmer, and G. F. Jones, "An Experimental and Theorotical Study of Sait-Gradient Solar Pund Intarface Behavfor," Proc. International Sol ar Emrgy Soclety Meeting, Houston, Texas, 1982 (Intornational Sol ar Energy Soctety, Newark, Del aware, 1982), D. I85.

53. D. P. Grfumer, G. F. Jones, J. Tafoya and T. J. Fitzgerald, "Development of - Point-Electrode Conductivity Salinometer with High Spatial Resolution for Use in Vary Saline Solutions," Rev. of Se1. Instrum., 54, 1744 (1983).

54. G. F. Jones, D. P. Grimmer, J. Tafoya and T. J. Fitzgerald, "Development of - Polnt. Fectrode Conductivity Sall nomatar with HIgh Spatial Resolution for Use In rury Saline Solutions, Proc. Intarnational Solar Enorgy Soctety Meating. Minneapol1s, Minnesuta, June 1983, (Intarnational Solar Energy Socfety. Newark, Delaware, 1983).

55. D. P. Grimar, G. F. Jones, J. Tafoya, and T. J. Fitzgerald, "Development of a Point-Electrode Conductivity Salinometer with High Spatial Resolution for Use in Vary Sall ne Solutions," Los Alamos Mational Laboratory report LA-9654-MS (1983).

56. V. Gartner, "Visualizati on of Partfcle 01 splacament and Flow in Stratffied Salt Wator." Exp. Flulds, 1, 58 (1983).

57. D. J. Baker, "A Technique for the Preclse Measurement of Small Fiuld Voloctties," Journal of Fluid Mechanics, 87, 417 (1978).

58. O. F. Jones, K. A. Mayer, J. C. Hesstrom, J. S. Orulcer, and D. P. Grimuer, - Design, Construction, and Initial Cparation of the Los Alamos Mational Laboratory Salt-Gradt ent Sol ar Pond," Proc. ASME-SED Meeting, Orlando, Florlda, Apr11 19-21, 1983 (Amertcan Soctety of Mechanteal Englneers, Naw York, 1983), 0.157.

59. G. F. Jones and K. A. Mayer, "Description and Inttial Operation of the Los Alamos National Laboratory Salt-Gradient Solar Pond," Los Alamos National Laboratory raport LA-UR-82-2694 (Octobar, 1982). 
60. C. J. Poplowsky, "Laboratory Simulatt on of the Solar Pond: Double Diffusive, Tharmohailne Systems," Mastars Thests, Purdue University, Departant of Mechanical Englneering, 1980.

61. J. Wu "Wind-Induced Turbulent Entral nant Across A Stable Density Interface," Journal of Fluid Mechanics, 61, 275 (1973).

62. E. K1t, E. Borent, and M. Yajada, "Yortical M1xing Induced by Wind and Rotating Screen In A Strattfied Fiuld in A Channol, "Journal Hydraulic Researeh, 18, 35 (1980).

63. D. L. Elwoll, T. A. Short, and P. C. Badgar, "Stabllity Crltarla for Solar (Therwal-Haline) Ponds, Proc. Intarnational Solar Enorgy Scelety Moeting. Orlando, Florida, June 6-10, 1977 (Intarnatiomal Solar Energy Soctety. Nowerk, Del aware, 1977) p. 29 (No. 16).

64. J. M. Broughton, "Experfiaents on Steady Layered Convection in a Doubly Diffusive System," Mastars Thesis, Colorado State University, Dopartmont of Mechanteal Enginoering, 1972.

65. B111 Inwtn, TVA, personal communtcation, Apr11, 1984. 